\title{
The Socio-Spatial Determinants of COVID-19 Diffusion: The Impact of Globalisation, Settlement Characteristics and Population
}

Thomas Sigler ( $\nabla$ t.sigler@uq.edu.au )

The University of Queensland https://orcid.org/0000-0002-7789-0916

Sirat Mahmuda

University of Queensland

Anthony Kimpton

University of Queensland

Julia Loginova

University of Queensland

Pia Wohland-Jakhar

University of Queensland

Elin Charles-Edwards

University of Queensland

Jonathan Corcoran

University of Queensland

Research

Keywords: COVID-19, Coronavirus, Spatial Diffusion, Globalisation, Urbanisation, Quantile regression

Posted Date: August 2nd, 2020

DOI: https://doi.org/10.21203/rs.3.rs-49170/v1

License: (9) This work is licensed under a Creative Commons Attribution 4.0 International License.

Read Full License 

The Socio-Spatial Determinants of COVID-19 Diffusion: The Impact of Globalisation,

12 Thomas Sigler $^{1 *}$, Sirat Mahmuda ${ }^{1}$, Anthony Kimpton ${ }^{1}$, Julia Loginova ${ }^{1}$, Pia Wohland-Jakhar ${ }^{1}$,

13 Elin Charles-Edwards ${ }^{1}$, Jonathan Corcoran ${ }^{1}$

$14{ }^{1}$ Queensland Centre for Population Research; The University of Queensland; St Lucia Queensland

154072 Australia

$16 \quad$ t.sigler@uq.edu.au

17

18

19

20

21

22 


\section{Abstract}

24 Background: COVID-19 is an emergent infectious disease that has spread geographically to

25 become a global pandemic. While much research focuses on the epidemiological and virological

26 aspects of the COVID-19 transmission, there remains a gap in knowledge regarding the drivers of

27 geographical diffusion between places. Here, we use quantile regression to model the roles of

28 globalisation, human settlement and population characteristics as socio-spatial determinants of

29 COVID-19 diffusion over a six-week period in March and April 2020.

30 Results: The quantile regression model suggest that globalisation and settlement population

31 characteristics related to high human mobility predict disease diffusion. Human development level

32 (HDI) and total population predict COVID-19 diffusion in countries with a high number of total

33 confirmed cases per million whereas larger household size, older populations, and globalisation

34 tied to human interaction predict COVID-19 diffusion in countries with a low number of total

35 confirmed cases per million.

36 Conclusions: The analysis confirms that globalisation, settlement and population characteristics

37 lead to greater disease diffusion, and primarily variables tied to high human mobility. These

38 outcomes serve to inform policies around 'flattening the curve', particularly as they related to

39 anticipated relocation diffusion from more- to less-developed countries and regions, and

40 hierarchical diffusion from countries with higher population and density. Epidemiological

41 strategies must be tailored to suit the range of human mobility patterns, as well as the variety of

42 settlement and population characteristics.

44 Keywords: COVID-19; Coronavirus; Spatial Diffusion; Globalisation; Urbanisation; Quantile 45 regression 


\section{Introduction}

47 The Coronavirus disease (COVID-19) was declared a global pandemic by the World Health

48 Organisation (WHO) on March $11^{\text {th }} 2020$ (1), just over two months after its outbreak in Wuhan,

49 China. Widely understood to have diffused geographically from a single point of origin in late

50 December 2019 (2, 3), COVID-19 has spread across more countries and in a more rapid manner

51 than previous similar outbreaks (e.g., the 1918 Spanish Influenza pandemic and the SARS

52 epidemic) (4), suggesting that the intensity of global connectivity $(5,6)$ was in part responsible for

53 its quick diffusion between territories and therefore transmission between individuals. This has

54 played out on an international scale, with early outbreaks beyond China in highly globalised

55 countries such as Japan and Singapore, and on a national scale with highly globalised subnational

56 regions more impacted than others. This is evidenced by a large number of early cases in countries'

57 densest, and often most affluent, regions_-Lombardia (Italy) (7), New York (the United States)

58 (8), Madrid (Spain) (9), and Tehran (Iran) (10), which all by far outnumbered cases in other regions

59 within their respective countries. The geographical concentration of the previous outbreaks in

60 particular cities (11) suggests that connectivity at the urban scale also plays an important role in

61 COVID-19 diffusion.

62 By the end of May 2020, only 12 states and territories have purportedly remained free of COVID-

63 19, including 10 small and isolated Pacific island states, and two countries relatively closed to

64 outside influence: Turkmenistan and North Korea (12). This suggests that in addition to

65 urbanisation, globalisation is an influential factor driving COVID-19 diffusion. Countries with

66 high numbers of confirmed cases (e.g. Italy, Spain, the United Kingdom and the United States) are

67 highly globalised nations with high human mobility, whilst those with fewer cases are without

68 exception less globalised, have significantly lower numbers of visitors, and in general less 
69 domestic mobility (13). By April $8^{\text {th }} 2020$, there had been 20277716 confirmed cases recorded

70 within the COVID-19 Data Repository by the Center for Systems Science and Engineering at

71 Johns Hopkins University (14). At the time the first cases were recorded in early January 2020,

72 spatial diffusion across borders was relatively slow. It took 45 days for the virus to spread to 30

73 countries, areas or territories (15). After this time, geographical diffusion accelerated and within

74 the next 45 days COVID-19 to reach nearly all global territories (15). To control the spread of the

75 virus within countries, governments have moved to limit international and intra-urban population

76 movements to varying extents. China was the first country to quarantine, implementing a lock-

77 down in the city of Wuhan on January $23^{\text {rd }} 2020$, and by early April 2020 an estimated one third

78 to half of the world's population was in some form of lock-down $(16,17)$.

79 Despite extensive epidemiological research and mathematical modelling of the COVID-19

80 transmission $(7,18-23)$, there has been a lacuna of work aiming to understand how social and

81 geographic factors converge to explain COVID-19 diffusion. In this paper, we demonstrate how

82 globalisation, human settlement and population characteristics of countries explain both the

83 number and diffusion patterns of COVID-19 cases, and how this relationship shifts over time.

84

\section{Background}

86 Infectious diseases diffuse over space and time through inherently geographical processes (24).

87 The geographical concept of spatial diffusion is defined as the spread of a phenomenon across

88 space (25), of which disease diffusion through interpersonal transmission is but one variant (24,

89 26). Here, we investigate the role of globalisation, settlement and population characteristics as

90 socio-spatial determinants of COVID-19 diffusion between countries as an outcome of

91 transmission between individuals. Although each new case is by definition a product of 
92 interpersonal transmission — both direct and indirect — diffusion can occur across large distances

93 as an outcome of human movement and mobility. Understandings of the viral transmission lie

94 more firmly within the academic domains of virology and epidemiology than diffusion, which is

95 a fundamentally geographic phenomenon that can be applied to many other forms of spread (for

96 example, innovation diffusion (25)).

97 Different underlying processes characterise types of spatial diffusion $(27,28)$. Expansion diffusion

98 identifies the general tendency for phenomena to spread 'outward', and infectious disease is most

99 associated with contagious diffusion, indicating direct transmission between neighbours due to

100 their physical proximity. The spread that occurs over a large distance from its origin is captured

101 by relocation diffusion, which is often mobilised by air travel or other modes of extra-local

102 transportation. Hierarchical diffusion characterises spread from large settlements to smaller ones.

103 In large and dense agglomerations the spreading occurs faster compared to small towns due to

104 larger populations and more intensive human contact. As infectious diseases spread through the

105 populations, different types of diffusion come into play, often in combination $(26,28)$. Sirkeci and

106 Yüceşahin (29) suggest that the spread of COVID-19 in March 2020 followed a relocation

107 diffusion pattern (spreading between countries), with hierarchical diffusion being observed only

108 in a few countries, including the United States, the United Kingdom, South Korea and Italy among

109 others.

110 On a global scale, mobility and connectivity between countries collectively contribute to disease

111 outbreaks across the globe, a finding supported by research on human rhinovirus, influenza, and

112 SARS $(30,31)$. Indeed, globalisation in its diverse forms has rendered physical (Euclidian)

113 distance increasingly less relevant as a proximity measure influencing diffusion. Though disease

114 vectors do in fact require human contact (even if indirect via fomites), the speed and ubiquity of 
115 global transportation and travel have led to time-space compression $(5,32)$, which progressively

116 reduce the time-distance required to connect any two global points. Thus countries with higher

117 levels of globalisation are more exposed to COVID-19, as are more globalised spaces within them

118 such as world cities (11).

119 In recent studies $(33,34)$, globalisation has been shown to be positively linked to the COVID-19

120 cases in that more globalised countries experience higher exposure to COVID-19 outbreaks.

121 Among its many related impacts, globalisation has increased the speed of global disease diffusion,

122 as public health studies have repeatedly acknowledged $(23,35)$. One study (34) focused on the

123 initial spread of COVID-19 based on Johns Hopkins University (JHU) data for March $16^{\text {th }}, 2020$

124 and found that more economically globalised countries were affected faster. COVID-19 has

125 rapidly spread via international air (36) and sea (37) travel connecting countries with high levels

126 of tourism and trade. Another study (33) focused on confirmed cases of COVID-19 by March 30 ${ }^{\text {th }}$,

1272020 across 138 countries and used a variety of sub-indices of globalisation (economic, social and

128 political) (38) as the main explanatory variables. The study found that almost all KOF globalisation

129 sub-indices have shown a robust and significant positive association with the number of COVID-

13019 confirmed cases, with social globalisation - that proxies migration and civil rights among other

131 measures - being the most important predictor both in magnitude and statistical significance (33).

132 Once a pathogen has begun to spread within a country, settlement characteristics impact disease

133 diffusion. In the case of infectious diseases, previous research suggests that large metropolitan

134 areas experience more significant spread due to the larger number of people, their closer proximity

135 and increased movement $(31,39-42)$. Both urbanisation and urban accessibility collectively

136 increase vulnerability to infectious disease spread (43) by creating the requisite preconditions for

137 higher numbers of human interactions wherein higher densities act to increase the intensity of such 
138 interactions (44). However, human settlements from around the world can also be very 139 heterogeneous with different patterns of human mobility and interactions and a highly variable 140 impact of an epidemic (45). To this end, we test human settlement characteristics, including 141 different levels of population density, urbanisation, and accessibility. Additionally, there are

142 marked differences in population characteristics - population size, development levels, household 143 size and age structure - affecting the spread of an infectious disease (45). We test this using four 144 population characteristics of individual countries: Human Development Index (HDI), population 145 aged over 65 , mean household size and national population size. These variables have been 146 selected based on recent studies that found them significant in explaining the COVID-19 outbreak 147 at the early stages of its spread $(8,29,46)$.

151 We employ quantile regression $(47,48)$ to test the impact of globalisation, settlement 152 characteristics and population characteristics on the cumulative total confirmed COVID-19 cases 153 per one million inhabitants over a six-week period from the $10^{\text {th }}$ week (ending March $4^{\text {th }}$ ) until the $15415^{\text {th }}$ week of 2020 (ending April $8^{\text {th }}$ ). Figure 1 shows the distribution of cases over the study period.

156 Figure 1. Distributions of cumulative confirmed COVID-19 cases per million population (log 157 transformed). Graphs show the $10^{\text {th }}$ week (ending March $4^{\text {th }}$ ) until the $15^{\text {th }}$ week (ending 158 April $\mathbf{8}^{\text {th }}$ ) of $\mathbf{2 0 2 0}$. The red line indicates the mean and the black lines quantiles. 


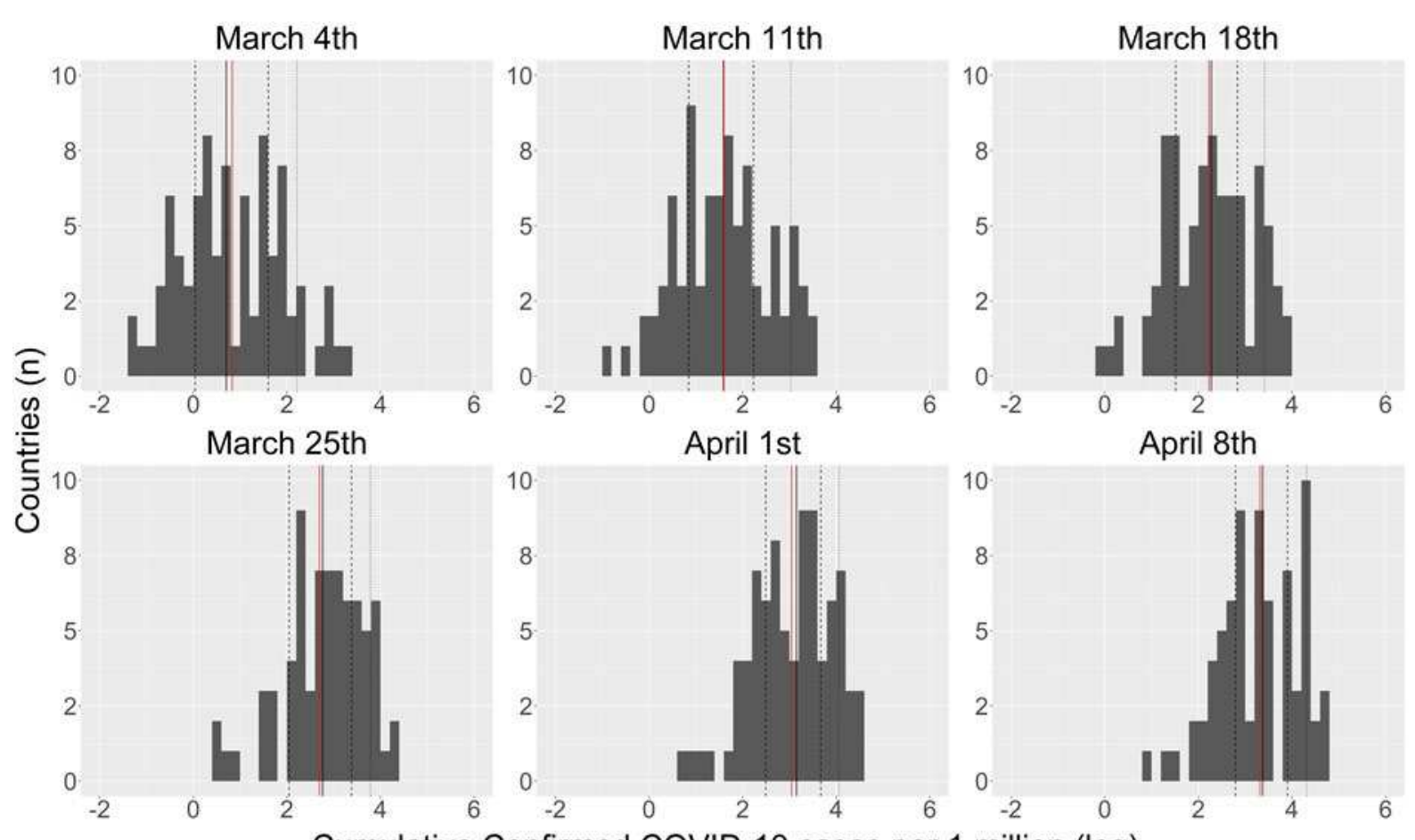

Cumulative Confirmed COVID-19 cases per 1 million (log)

160 Table 1 lists the variables in the model, with the source, units and year of each.

161 Table 1. List of independent variables to explain the diffusion of confirmed COVID-19_cases.

\begin{tabular}{|c|c|c|c|c|}
\hline Variable Description & Category & Units (Transformation) & Source & Year \\
\hline $\begin{array}{l}\text { Interpersonal } \\
\text { Globalisation }\end{array}$ & Globalisation & $\begin{array}{l}\text { Index Value (100 Point } \\
\text { Scale) }\end{array}$ & $\begin{array}{l}\text { Swiss Economic Institute } \\
\text { (KOF) }\end{array}$ & 2019 \\
\hline Trade Globalisation & Globalisation & $\begin{array}{l}\text { Index Value (100 Point } \\
\text { Scale) }\end{array}$ & $\begin{array}{l}\text { Swiss Economic Institute } \\
\text { (KOF) }\end{array}$ & 2019 \\
\hline Financial Globalisation & Globalisation & $\begin{array}{l}\text { Index Value (100 Point } \\
\text { Scale) }\end{array}$ & $\begin{array}{l}\text { Swiss Economic Institute } \\
\text { (KOF) }\end{array}$ & 2019 \\
\hline Urbanisation Rate & Settlement & National (Percent) & World Bank & 2018 \\
\hline Population Density & Settlement & $\begin{array}{l}\text { Log transformed value of } \\
\text { Inhabitants per square } \\
\text { kilometre }\end{array}$ & World Bank & 2018 \\
\hline Urban Density & Settlement & $\begin{array}{l}\text { Inhabitants per square } \\
\text { kilometre in Densest } \\
\text { Metropolitan Area }\end{array}$ & Demographia & 2020 \\
\hline Areal Accessibility & Settlement & $\begin{array}{l}\text { The area-weighted } \\
\text { average for driving time } \\
\text { to a location with at least } \\
1,500 \text { inhabitants per } \\
\text { square kilometer }\end{array}$ & Weiss et al (2018) & 2018 \\
\hline Human Development & Population & Index Value & $\begin{array}{l}\text { United Nations } \\
\text { Development Programme }\end{array}$ & 2018 \\
\hline
\end{tabular}


Population aged 65 and Population Percent Age 65+ over

Household Size

Population

Mean Number of Household Members

Population

Population Total population
United Nations,

Department of Economic and Social Affairs Population Division United Nations, 2019 Department of Economic and Social Affairs Population Division United Nations

163 During the six-week period of the study period, the number of cases increased by 1433 per cent

164 and the number of countries and territories affected more than doubled, counting those enumerated

165 within the COVID-19 Data Repository by the Center for Systems Science and Engineering at 166 Johns Hopkins University (JHU) (14). Figures 2 and 3 show the geographical (Figure 2) and 167 temporal spread (Figure 3) of COVID-19 over time.

Figure 2. Choropleth map of confirmed cases of COVID 19 per million population for the 84

170 countries included in the analysis over weeks 10 to 16 (ending March $4^{\text {th }}$ and April 8th 2020, 171 respectively). 

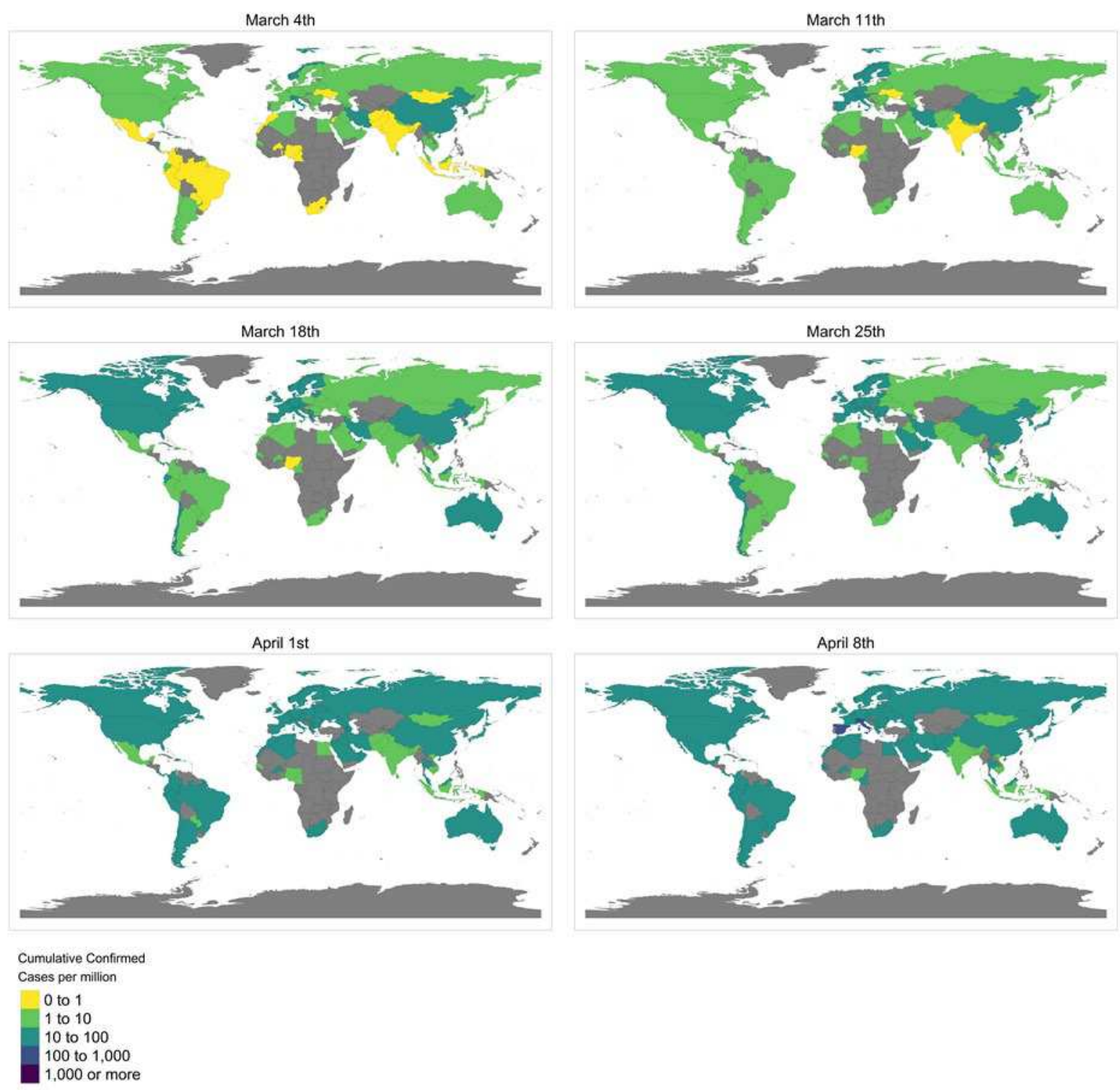

173 Figure 3. Diffusion of Covid-19 cases per million population (log transformed) over weeks $17410-15$ (ending $4^{\text {th }}$ March and April $8^{\text {th }}$ 2020, respectively) across 84 countries. 


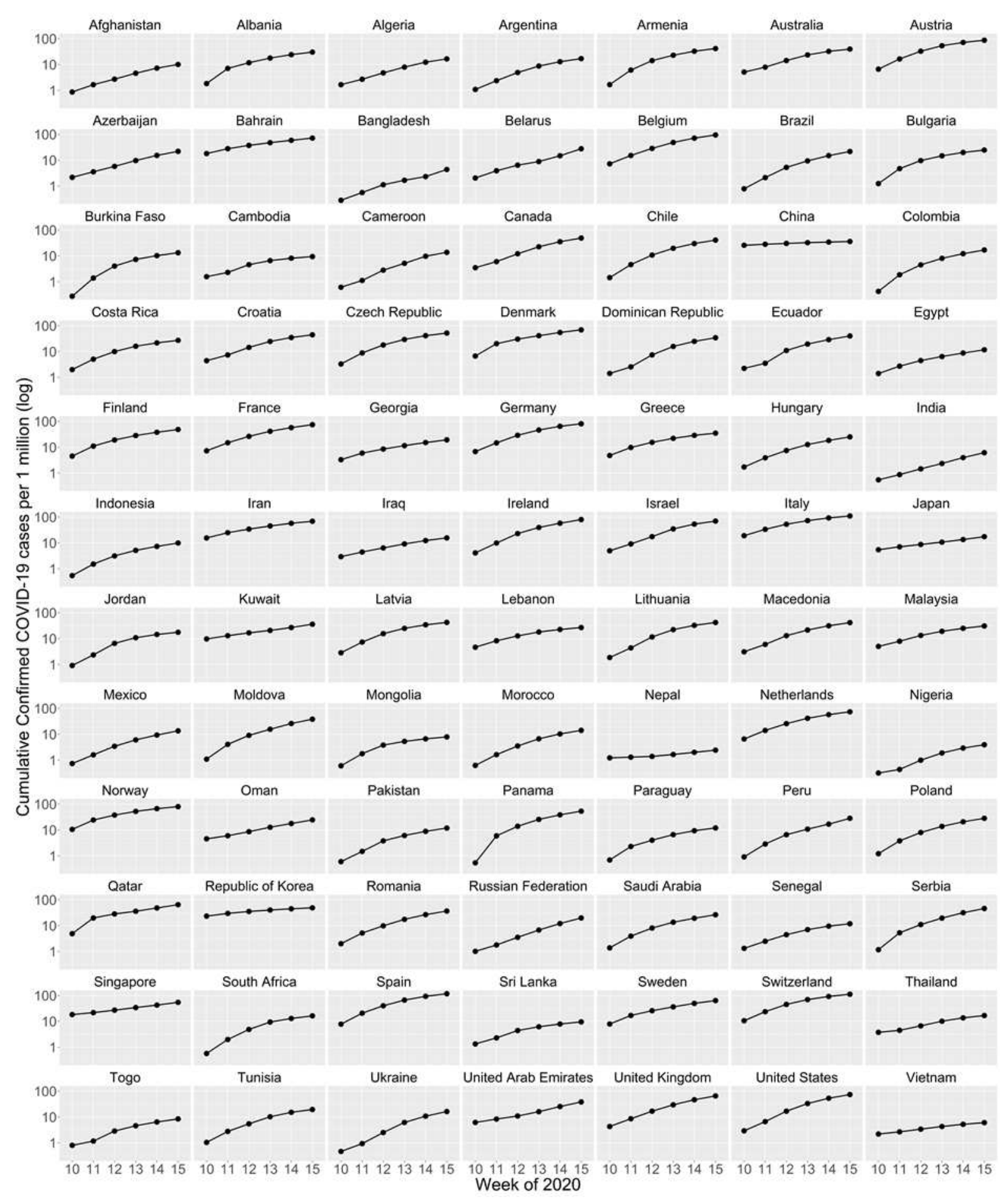

176 The dependent variable in the quantile regression model is the number of cumulative total of

177 confirmed COVID-19 cases per one million inhabitants (log-transformed) by country (or territory)

178 and by week. The denominator for the dependent variable is the 2019 mid-year population by 
179 country drawn from the United Nations World Population Prospects (49). 84 countries had 180 consistent available data for the duration of the study period and were therefore included in the 181 model. Data on national COVID-19 cases were extracted from the JHU repository on May $13^{\text {th }}$ 182 2020. Although some sources suggest that drawing data from this, and similar global repositories 183 is problematic (50) due to data inconsistency, intentional misreporting, and disparate collection 184 techniques $(51)$, we align with a rapidly growing number studies published $(52,53)$ in other outlets 185 recognizing the immense efforts of the Johns Hopkins team in both compiling, and triangulating 186 the data set with a variety of data sources.

187 Quantile regression allows us to go beyond the mean relationship between the response and the 188 predictor variables to reveal statistical relationships at different quantiles of the distribution (47, $18948,54,55)$. In this way we detail our discussion on how the globalisation, settlement 190 characteristics, and population characteristics affect global diffusion of COVID-19 cases along 191 across its entire distribution. The technique explains the differential effects that socio-spatial 192 factors have across points along the distribution that mean models cannot account for, which in 193 this instance can identify contribute that explain COVID-19 diffusion at either end of the pandemic 194 spectrum.

195 Although mean regression models are highly sensitive to outliers, different quantile estimations 196 can also be influenced by outliers at different locations (quantile) $(56,57)$. For example at the $50^{\text {th }}$ 197 quantile in the last three weeks of the study, China, Iran and Japan stand out as influential 198 observations which might have overly impacted the significance of each variable.

199 To understand the role of globalisation in COVID-19 diffusion, we test three variables from the 200 KOF globalisation index $(38,58,59)$ : de facto interpersonal globalisation, de facto financial 201 globalisation and de facto trade globalisation. These sub-indices proxy migration, tourism and 
202 business flows, which have been positively associated with outbreaks of infectious diseases by 203 exposing countries to the outside world (33-35, 40, 60-62). Globalisation variable 1 is de facto 204 interpersonal globalisation is a KOF sub-index of social globalisation that includes indicators of 205 international traffic, transfers, international tourism, international students and migration (38). An 206 early study of the COVID-19 spatial diffusion (29) shows that the volume of migration flows has 207 been a strong indicator for the international spread of the pandemic. Globalisation variable 2 is $d e$ 208 facto trade globalisation, another KOF sub-index of economic globalization that reflects trade in 209 goods and services as well as trade partner diversity (38). Globalisation variable 3 is de facto 210 financial globalisation, a KOF sub-index of economic globalisation. It is comprised of measures 211 of foreign direct investment, portfolio investment, international debt, international reserves, and 212 international income payments (38).

213 To understand the role of settlement characteristics in COVID-19 diffusion, we test four variables 214 that measure various national-scale dimensions, including: urbanisation rate, population density, 215 maximum urban population density, and areal accessibility (measures the average drive time of 216 the national population from smaller to larger settlements (63)). These represent human interaction 217 within national boundaries, with recent publications demonstrating that diffusion happens more 218 rapidly in cities that are dense, well-connected, and accessible $(11,29,42-44)$. Settlement variable 2191 is urbanisation rate, defined as the proportion of a national population located in cities or 220 metropolitan regions (national definitions vary). We selected this variable as cities are more prone

221 to early disease diffusion than rural areas due to higher concentration of interaction and movement

222 in urban areas (42). COVID-19 has been preliminary found to diffuse faster in more populous

223 urban areas in the United States (64). Settlement variable 2 is population density, defined as the 224 population per square kilometre across a national territory. Population density proxies the higher 
225 intensity of human interaction which makes disease transmission more likely. The literature shows

226 a significant effect of population density on the outbreak of infectious diseases (44). While a

227 previous study (29) found no significant relationship between population density and total

228 confirmed COVID-19 cases, there is a broader literature that shows an association between

229 population density and the outbreak of infectious diseases (44).

230 Settlement Variable 3 is urban density [maximum], defined as the population per square kilometre

231 of the densest city in a country. This variable has been selected based on previous studies that

232 documented a higher sensitivity of large cities (global cities) to the spread of infectious diseases

$233(11,31)$. Settlement Variable 4 is areal accessibility, defined as an area-weighted average of

234 driving time to locations with at least 1,500 inhabitants per square $\mathrm{km}(63)$. This variable has been

235 selected based on a previous study (43) in which the authors argue that extended urbanisation may

236 result in increased vulnerability to an infectious disease spread. Urban accessibility captures the

237 variations in suburbanisation and peri-urbanisation across countries.

238 To understand the role of national population characteristics in COVID-19 diffusion, we employ

239 HDI, population age structure $(65+)$, median household size, and population size. Research

240 suggests that COVID-19 is more likely to spread in more-developed countries with higher levels

241 of international migration than in countries with lower levels of development and migration (33).

242 Affluent, healthy and educated populations (HDI) are more likely to be highly mobile. Although

243 larger household sizes and national populations have also been shown to increase COVID-19

244 cases, these are not clear-cut relationships (8). Older populations or populations with higher

245 mortality rates are more likely to get tested than younger populations that may be asymptomatic

246 (46, 65). Population variable 1 is HDI (Human Development Index), which captures a holistic

247 picture of individual countries and has been used as an indicator of the macro environment in a 
248 previous study (29) written in the early period of the pandemic. The study found that each unit

249 increase in the HDI score is associated with five more confirmed COVID-19 cases. Populations in

250 countries with higher HDI are more affluent, healthier, and better educated, meaning that their

251 overall mobility potential would be higher. Population variable 2 is population aged 65 and over

252 (\%), which is the proportion of the population aged 65 years and over. We hypothesise that in early

253 stages of the pandemic, case detection is higher in countries with older populations due to the

254 higher burden of mortality among older adults (46). COVID-19 transmission may remain

255 undetected longer in younger populations (65). Population variable 3 is household size (mean) is

256 the average number of people per dwelling. Individuals in larger households interact with more

257 people including once stay-home measures are applied. The analysis of demographic and

258 socioeconomic determinants of COVID-19 testing in New York shows a very strong correlation

259 between the cases of infection in the population and household size (8). Population variable 4 is

260 population (n), which is a demographic variable with a direct relation to the pool size for the

261 potentially infected population. Population size was considered as a moderating variable in a

262 previous study (29) that found that "a one person increase in population size indicates over 1.6

263 more COVID-19 cases" (p. 385) thus more populous countries have greater potential for exposure.

264 Even when normalised on a per capita basis, the likelihood of new cases is still higher in large

265 countries than small countries. The table below (Table 2) provides summary statistics on 266 globalisation, settlement characteristics and population variable data.

268 Table 2. Descriptive Summary of Independent Variables

\begin{tabular}{llllll}
\hline Independent Variable & \multicolumn{4}{c}{ Median Mean St. Dev. Min } & Max \\
\hline Confirmed cases per million by March 4 $4^{\text {th }}[\log ]$ & 0.71 & 0.83 & 1.10 & -1.29 & 3.25 \\
Confirmed cases per million by March $11^{\text {th }}[\log ]$ & 1.59 & 1.60 & 1.00 & -0.83 & 3.52
\end{tabular}




\begin{tabular}{lccccc} 
Confirmed cases per million by March $18^{\text {th }}[\log ]$ & 2.28 & 2.23 & 0.91 & -0.01 & 3.97 \\
Confirmed cases per million by March $25^{\text {th }}[\log ]$ & 2.77 & 2.69 & 0.88 & 0.50 & 4.29 \\
Confirmed cases per million by April $1^{\text {st }}[\log ]$ & 3.15 & 3.04 & 0.86 & 0.70 & 4.53 \\
Confirmed cases per million by April $8^{\text {th }}[\log ]$ & 3.38 & 3.32 & 0.83 & 0.89 & 4.76 \\
Interpersonal Globalisation [index] & 68.50 & 64.80 & 20.70 & 22.70 & 96.50 \\
Trade Globalisation [index] & 62.80 & 57.80 & 21.50 & 21.20 & 99.20 \\
Financial Globalisation [index] & 72.70 & 69.20 & 19.10 & 21.30 & 97.30 \\
Urbanisation [rate] & 72.00 & 68.60 & 19.60 & 18.50 & 100.00 \\
Population Density [log] & 1.97 & 1.95 & 0.57 & 0.31 & 3.90 \\
Urban Density [maximum] & 5650 & 7686 & 6251 & 1300 & 41000 \\
Areal Accessibility [mean] & 111 & 158 & 116 & 30 & 577 \\
Human Development [index] & 0.80 & 0.79 & 0.12 & 0.43 & 0.95 \\
Aged over 65 [\%] & 11.00 & 11.40 & 6.70 & 1.09 & 27.60 \\
Population [million] & 18 & 76 & 219 & 1 & 1432 \\
Household Size [mean] & 3.36 & 3.78 & 1.16 & 2.05 & 8.66 \\
\hline
\end{tabular}

271 Results

272 Globalisation, settlement characteristics, and population characteristics all influence COVID-19

273 diffusion, but do so differently at different points on the distribution and at different points in time.

274 Figure 4 visualises the standardised relationship of each factor with the number of (log275 transformed) confirmed cases per million at the $25^{\text {th }}, 50^{\text {th }}, 75^{\text {th }}$ and $90^{\text {th }}$ quantiles for each of week 276 of the six week period.

277

278 Figure 4. Standardised coefficient value of confirmed COVID-19 cases at the 25th, 50th, 279 75th and 90th quantiles the $10^{\text {th }}$ week (ending March $4^{\text {th }}$ ) until the $15^{\text {th }}$ week of 2020 (ending 280 April 8th). 

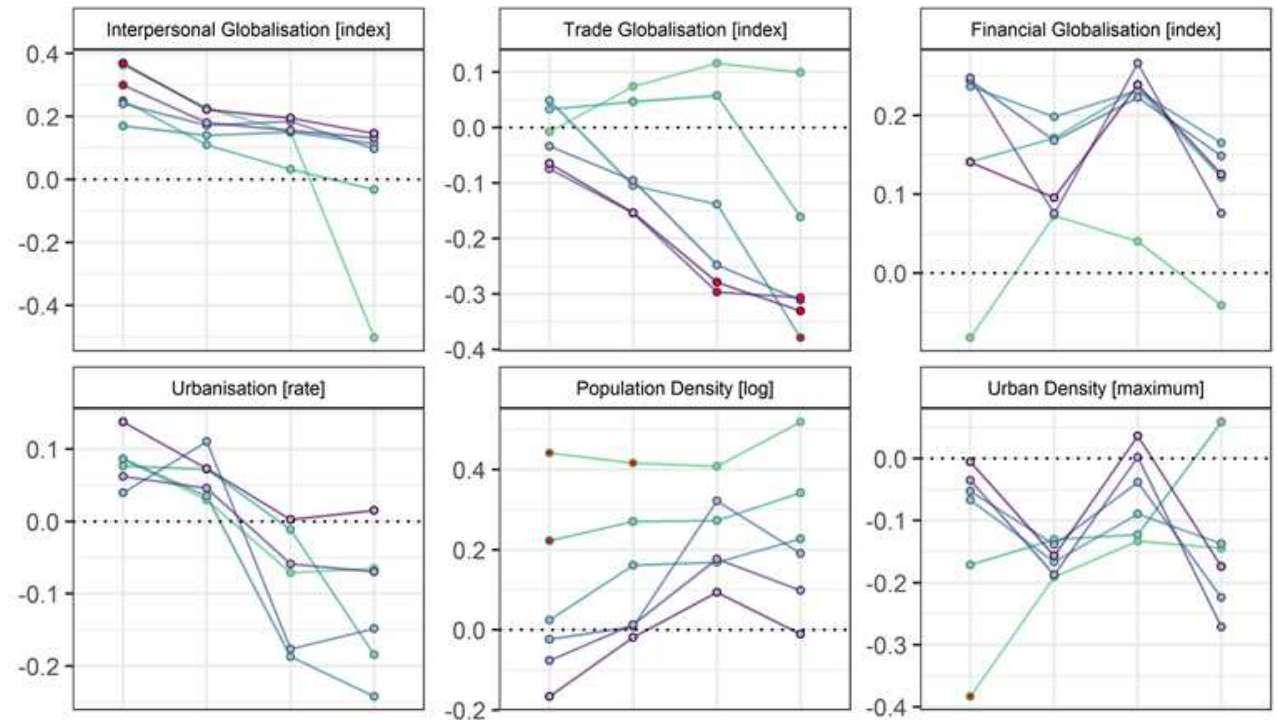

Week Ending:
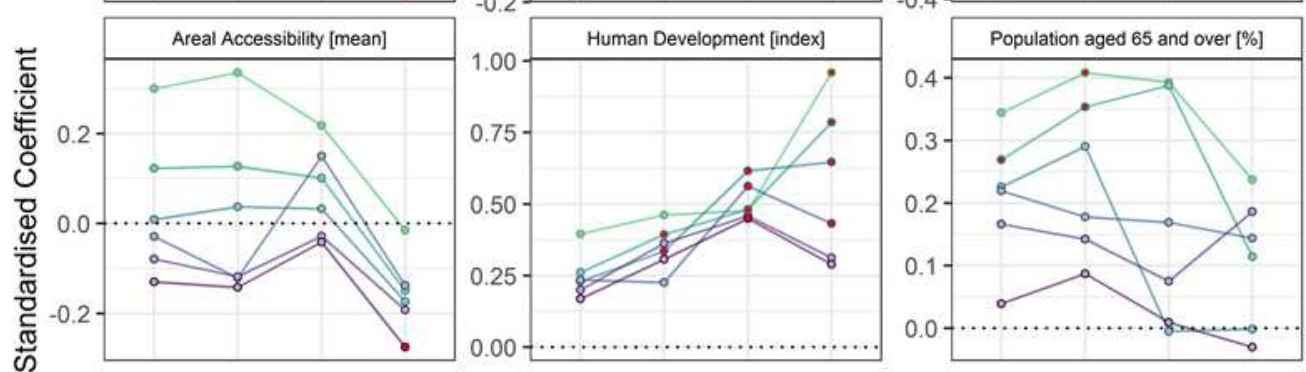

$\rightarrow-$ March 4th

$\rightarrow-$ March 11th

$\rightarrow$ March 18th

-o- March 25th

$\rightarrow$ April 1st

$\rightarrow$ April 8th
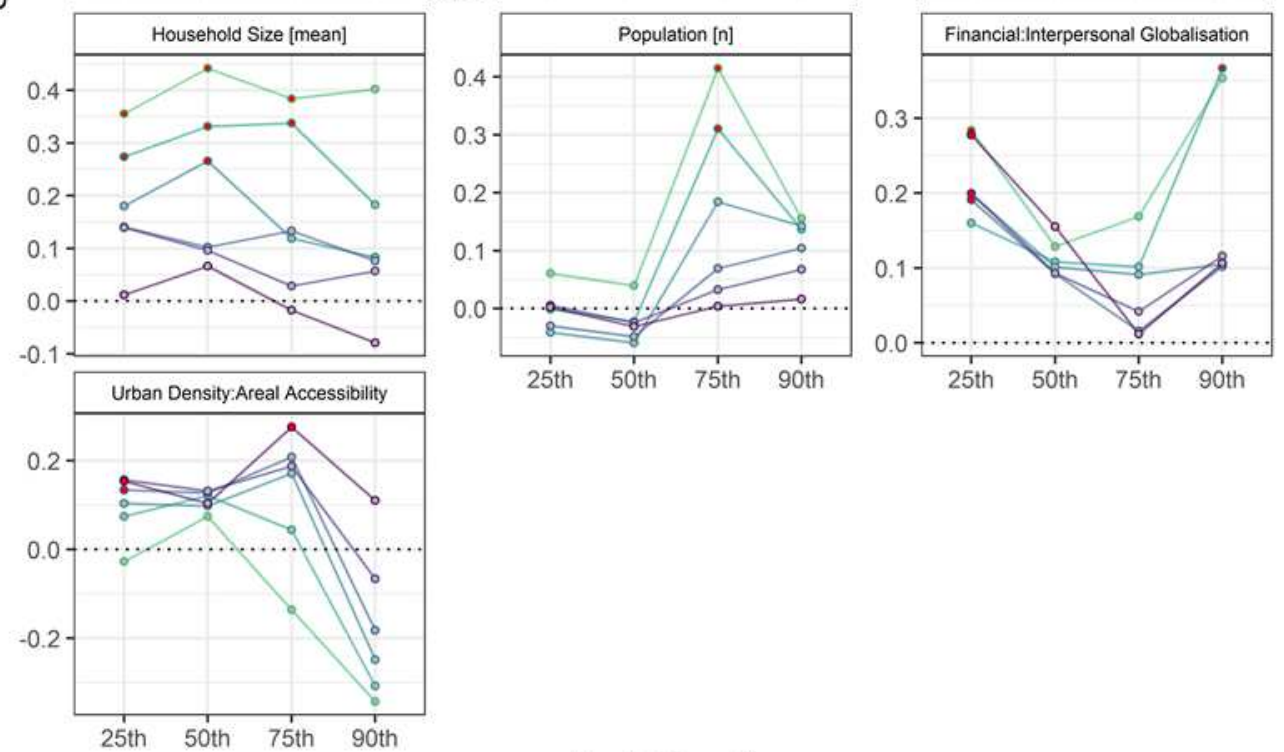

\section{Statistically:}

- significant

- insignificant

Model Quantile

282 In the early stages (Weeks 10,11), population characteristics were the most significant variables

283 in explaining COVID-19. HDI was found to be the most important and significant variable 
$285\left(75^{\text {th }}\right.$ and $90^{\text {th }}$ quantiles) and within the earlier weeks (corroborating findings of an earlier study

286 (29)), decreasing in importance over time. Aged population (65+) is significant only in early weeks

287 at the $25^{\text {th }}$ and $50^{\text {th }}$ quantiles, but strong collinearity with HDI suggests these are related in causality

288 (See Additional file 7). Both HDI and Population aged 65+ tend toward zero in later weeks,

289 indicating a muted impact as time goes on. Population size and household size are significant and

290 positive in earlier weeks and both tend toward zero in later weeks. Population size is significant at

291 the $75^{\text {th }}$ quantile whereas household size is significant throughout the $25^{\text {th }}, 50^{\text {th }}$ and $75^{\text {th }}$ quantiles.

292 Settlement characteristics had mixed effects in explaining COVID-19 diffusion. Population

293 density initially (Week 10) had a strong positive effect at the mean, and at the $25^{\text {th }}, 50^{\text {th }}$, and $75^{\text {th }}$

294 quantiles but waned both in strength and significance with time. Maximum urban density exerts

295 negative influence on COVID-19 diffusion throughout the distribution, but is strongest at the mean

296 and only significant in the first week of our study. Again, early COVID-19 diffusion is tied to

297 density, but the influence of a single (or multiple) densely populated settlements has less impact

298 and significance over time. In contrast, areal accessibility is negatively associated with COVID-

29919 diffusion in later weeks but only at the $90^{\text {th }}$ quantile, meaning its effect is significant in countries

300 with a high number of new cases per million. A negative relationship suggests that the highest

301 number of total cases are associated with greater access to cities, and that as this is reduced, so are

302 the number of confirmed cases per million.

303 Globalisation has the weakest effect of the three classes of variables, and its effects are mixed both

304 in terms of which portion of the distribution is impacted and the type of globalisation.

305 Interpersonal globalisation has a weak positive effect at the mean and $25^{\text {th }}$ quantile, particularly in

306 early weeks. While financial globalisation was not a reliable predictor, it interacted with

307 interpersonal globalisation towards the start of the study period at both tails of the distribution. 
308 Trade globalisation is the most prominent in scaled terms and given that it explains suppressed 309 COVID-19 spread, suggesting that countries with strong import and export ties are better placed 310 to slow the spread following the closure of borders.

311 Greater significance in terms of which globalisation and settlement characteristics explain 312 diffusion was added through two interaction terms, added based on goodness-of-fit. The 313 globalisation interaction term is between de facto financial globalisation and de facto interpersonal 314 globalisation. This interaction term takes into account the combined effect of international travel 315 and the level of financial globalisation. This interaction effect is significant and positive, 316 particularly throughout the lower quantiles and in the early weeks. This is to say that countries

317 with a low number of COVID-19 cases per million are likely to receive new cases if conditions of 318 both high financial globalisation and interpersonal globalisation are met, generally both related to 319 intensity of human mobility flows.

320 The settlement interaction term is between urban density of the largest city of the country and the 321 (lack of) accessibility of smaller settlements. This interaction term accounts for the hierarchical 322 connectivity between settlements of different sizes within the country and thus it proxies the 323 primacy, as many countries are poorly connected overall but have large and dense capital or 324 primate cities. This interaction yields a mostly positive effect (up to the $75^{\text {th }}$ quantile), and is 325 significant and positive in the distribution in the final week of the analysis. Thus we can attribute 326 diffusion of COVID-19 to urban primacy, especially in countries at the low end of the distribution, 327 and particularly in later weeks. In other words, countries with poorly connected urban systems are 328 more prone to disease diffusion, perhaps counter to intuition. 
331 With a vaccine against SARS-CoV-2 unavailable, COVID-19 is, and will continue to be, a

332 significant detriment to human health outcomes. Of the variables tested in our diffusion model,

333 population and settlement characteristics have both the strongest, and most significant impact on

334 new COVID-19 cases per one million inhabitants. Notably, among countries with high early

335 infection rates HDI is by far the strongest predictor of new cases. HDI has a strong, albeit

336 weakening, positive association with COVID-19 diffusion across the six week period, suggesting

337 some level of hierarchical diffusion from more developed countries to less developed countries,

338 and relocation diffusion between more-developed countries with high mobility (e.g. within

339 Europe). Particularly in the early weeks, other population and settlement characteristics such as

340 population aged $65+$, household size, and population density explain diffusion, but their effect is

341 almost immediately dampened in successive weeks. The lasting impact of HDI, and the muted

342 impacts of other population and settlement characteristics, is perhaps best explained by COVID-

343 19's impacts on mobility. Although more-developed countries may have been more successful in

344 implementing early lock-down measures, they also had much higher overall levels of both

345 international and internal mobility, hence why settlement characteristics play such an important

346 role in Week 10 but not afterward.

347 Of the globalisation variables, interpersonal globalisation has the strongest and most significant

348 effect, particularly when interacting with the financial globalisation variable. Conversely, trade

349 globalisation has a negative impact, and the impacts of all three globalisation types appear to be

350 stronger toward the latter weeks. The impact of globalisation in later weeks may be somewhat

351 counterintuitive, as one might expect more globalised countries to experience COVID-19 diffusion

352 in earlier stages, but it also reflects the fact that the economies of more globalised countries are

353 tied to 'openness', with strong disincentives for shutting borders and enforcing other 'global' 
354 restrictions. To this end, trade globalisation is not associated with human mobility as much as

355 financial globalisation and interpersonal globalisation, with the latter incorporating both tourism 356 and migration.

\section{Conclusion}

359 Globalisation, settlement, and population characteristics are all important in explaining COVID-

36019 diffusion, but significant at different points on the distribution and points in time. The quantile

361 regression model reveals that urbanisation and density generally exert a positive effect on disease

362 diffusion early on, that over time tends toward zero. Conversely, variants of globalisation exert

363 diverse effects, with trade globalisation exerting a negative effect on COVID-19 diffusion that

364 diverges from the positive effects associated with financial and interpersonal globalisation. The 365 impacts of settlement characteristics is mixed, but generally has the greatest effect at the upper and 366 lower ends of the distribution, and more so in the initial weeks.

367 Our model suggests that the impacts of non-local diffusion outweigh the geographical effects of 368 diffusion tied to adjacency. There is no evidence to suggest that neighbouring countries spread 369 disease across borders, at least not to the degree that openness via globalisation, or local 370 transmission via urbanisation, do. Although both infectious and contagious diffusion are present

371 throughout the study period via interpersonal contact, our results indicate that relocation diffusion

372 precedes hierarchical diffusion as the disease is first carried across long distances via global 373 mobility, and later diffused within countries from single or multiple points of entry, which are

374 typically the largest and/or most globalised cities. Though this may seem self-evident, further 375 research should focus on the impacts and effects of policy on diffusion, which is likely to have had 376 a strong impact across the study period $(16,66,67)$. 
377 Perhaps the finding that more-developed countries experience higher disease diffusion before less-

378 developed countries may be perceived as auspicious, given that countries with more economic

379 wealth and more advanced health care systems are better able to cope with pandemic conditions.

380 However, there is clear evidence of diffusion: from more-developed to less-developed, and to a

381 lesser extend from urbanised on non-urbanised. As COVID-19 is a disease whose diffusion is

382 reliant on interpersonal transmission, we find that both relocation diffusion (tied to global

383 mobility) and hierarchical diffusion (tied to population and settlement characteristics) are

384 simultaneously acting on countries.

385 To date, the primary public health initiatives to curb disease diffusion have been travel bans (border

386 closures) and stay-home orders, which restrict gatherings. Both have shown clear effectiveness in

387 curbing disease diffusion $(16,66)$ as the recent case of New Zealand vanquishing COVID-19 has

388 proven (68). As disease diffusion progresses, implanting these measures at increasingly small

389 scales will be necessary as restricting human mobility has proven the most effective measure

390 against spread.

393 Methods

394 An Ordinary Least Squares regression (OLS; formula 1) was repeated for each period (weeks 10 395 to 15). We introduce two interaction terms - one at the global-scale and another at the local-scale.

396 At the global-scale, the interaction term is between de facto financial and interpersonal 397 globalisation. Financial globalisation captures direct foreign investment, international reserves, 398 and international income payments that induce movement of skills and labour. Financially 399 globalised nations are typically global centres of business and related services and thus, generate 
global business travel and interaction. As such, the interaction between financial and interpersonal

401 globalisation captures international travel related to business. In contrast, we anticipate that the

402 national-scale interaction between maximum urban density (the largest National City) and areal

403 accessibility will have growing importance in later weeks once national borders close and thus

404 COVID-19 exposure will typically occur within national borders and at home. As such, this

405 interaction represents the connectivity between the smaller urban growth centres and the economic

406 centre of the country.

$$
y_{n}=\beta_{0}+\beta_{1} x_{1}+\beta_{1} x_{1}+\cdots+\beta_{n} x_{n}+\varepsilon_{n}
$$

408 Once the least parsimonious set of variables was identified, quantile regression was used to explain 409 the global diffusion and transmission of COVID-19 according to key globalisation and national 410 variables. This regression revealed how the influences of log-transformed rate of COVID-19 411 confirmed cases vary across the quantiles of the distribution (69). As such, this regression does not 412 assume there is normality nor uniformity in how COVID-19 is diffused and transmitted between 413 and within countries. This regression revealed how the influences of log-transformed rate of 414 COVID-19 confirmed cases vary across the quantiles of the distribution (69). As such, this 415 regression does not assume there is normality nor uniformity in how COVID-19 is diffused and 416 transmitted between and within countries. The $\tau$ were placed at the 25 th, 50 th, 75 th, and 90 th 417 quartiles according to the conventions of disease mapping (70-72). Again the quantile regression 418 was iterated for each week using formula 2 (69):

$$
Q^{\tau}\left(y_{i} \mid x_{i}\right)=\beta_{0}^{(\tau)}+\beta_{1}^{(\tau)} x_{1}+\cdots+\beta_{n}^{(\tau)} x_{n}+\varepsilon^{(\tau)}
$$

$420 \quad$ Where $\mathrm{i}=1,2, \ldots \ldots \ldots, \mathrm{n}$

$$
Q^{\tau}\left(y_{i} \mid x_{i}\right)=\beta_{0}^{(\tau)}+\beta_{1}^{(\tau)} x_{1}+\cdots+\beta_{n}^{(\tau)} x_{n}+\varepsilon^{(\tau)}
$$

$422 \quad$ Where $\mathrm{i}=1,2, \ldots \ldots \ldots, \mathrm{n}$ 
423 The output tables for these regression models in Additional Files 1-6. Lastly, the specific R

424 functions used for modelling are quantreg::rq for quantile regression.

425 Koenker and Machado (1999) suggest a goodness of fit, $\mathrm{R}_{1}(\tau)$ analogous to R-squared in simple

426 linear regression and argues that $\mathrm{R}_{1}(\tau)$ gives a local measure of goodness of fit for a particular

427 quantile rather than a global measure of goodness of fit over the entire conditional distribution

428 (73). The median (50th quantile) is the point at which the model is weakest, suggesting likewise

429 that a mean model would have been a poor fit. The model is strongest at the $25^{\text {th }}$ and $90^{\text {th }}$ quantiles,

430 indicating that the model is best fit to serve countries with a low number of cases (these are mostly

431 small countries with low HDI) and the $90^{\text {th }}$ is where most of the existing cases are (generally larger

432 countries with high HDI). The quantile regression model is the best fit in the first week, with

433 progressively less significance and explanatory power. This suggests that policy may be most

434 effective in early weeks, as known socio-spatial conditions can be targeted through specific public

435 interventions.

436 Declarations

437 Ethics approval and consent to participate

438 Not applicable.

439 Consent for publication

440 Not applicable.

441 Availability of data and materials

442 The dataset supporting the conclusions of this article is available from the COVID-19 Data

443 Repository by the Center for Systems Science and Engineering (CSSE) at Johns Hopkins

444 University, https://github.com/CSSEGISandData/COVID-19.

\section{Competing interests}


446 The authors declare that they have no competing interests.

447 Funding

448 Not applicable.

449 Authors' contributions

450 All authors contributed equally to the research conception and design. TS, SM, AK, JC

451 contributed to data collection, harmonization, data analysis and interpretation. JL, PWJ, ECE

452 contributed to drafting the work. All authors read and approved the final manuscript.

453

454 Acknowledgements

455 Not applicable.

456 


\section{References}

458 1. WHO. WHO Director-General's opening remarks at the media briefing on COVID-19, 11

459 March 20202020 12/03/2020; 2020(5.5.). Available from:

460 https:/www.who.int/dg/speeches/detail/who-director-general-s-opening-remarks-at-the-media-

461 briefing-on-covid-19---11-march-2020.

462 2. Lu H, Stratton CW, Tang YW. Outbreak of pneumonia of unknown etiology in Wuhan, 463 China: The mystery and the miracle. J Med Virol. 2020;92(4):401-2.

464 3. Velavan TP, Meyer CG. The COVID-19 epidemic. Trop Med Int Health. 2020;25(3):27846580.

466 4. Wu F, Zhao S, Yu B, Chen YM, Wang W, Song ZG, et al. A new coronavirus associated 467 with human respiratory disease in China. Nature. 2020;579:265.

$468 \quad 5 . \quad$ Harvey D. The condition of postmodernity. Oxford: Blackwell; 1989.

469 6. Castells M. The rise of the network society. Sussex: John Wiley \& Sons; 2011.

470 7. Giordano G, Blanchini F, Bruno R, Colaneri P, Di Filippo A, Di Matteo A, et al. Modelling 471 the COVID-19 epidemic and implementation of population-wide interventions in Italy. Nat Med. 472 2020;doi:10.1038/s41591-020-0883-7.

473 8. Borjas GJ. Demographic determinants of testing incidence and COVID-19 infections in 474 New York City neighborhoods. 2020. National Bureau of Economic Research. Available from: 475 https://www.nber.org/papers/w26952.

476 9. Perez-Bermejo M, Murillo-Llorente MT. The fast territorial expansion of the Covid-19 in 477 Spain. Int J Epidemiol. 2020:JE20200123.

478 10. Tuite AR, Bogoch II, Sherbo R, Watts A, Fisman D, Khan K. Estimation of coronavirus 479 disease 2019 (COVID-19) burden and potential for international dissemination of infection from 480 Iran. Ann Intern Med. 2020;doi:10.7326/M20-0696.

481 11. Ali SH, Keil R. Global cities and the spread of infectious disease: The case of severe acute 482 respiratory syndrome (SARS) in Toronto, Canada. Urban Stud. 2006;43(3):491-509.

483 12. WHO. Coronavirus disease (COVID-19) Situation Report - 1142020 14/05/2020; 2020. 484 Available from: $\quad$ https:/www.who.int/docs/default-source/coronaviruse/situation485 reports/20200513-covid-19-sitrep-114.pdf?sfvrsn=17ebbbe 4 . 
486 13. Bell M, Charles-Edwards E, Ueffing P, Stillwell J, Kupiszewski M, Kupiszewska D. 487 Internal migration and development: comparing migration intensities around the world. Popul Dev 488 Rev. 2015;41(1):33-58.

489 14. Dong E, Du H, Gardner L. An interactive web-based dashboard to track COVID-19 in real 490 time. Lancet Infect Dis. 2020;20(5):533-4.

491 15. WHO. WHO-COVID-19-global-data2020 14/05/2020. Available from: 492 https://covid19.who.int/.

493 16. Wells CR, Sah P, Moghadas SM, Pandey A, Shoukat A, Wang Y, et al. Impact of 494 international travel and border control measures on the global spread of the novel 2019 coronavirus 495 outbreak. Proc Natl Acad Sci U S A. 2020;117(13):7504-9.

496 17. Koh D. COVID-19 lockdowns throughout the world. Occup Med. 2020:kqaa073.

497 18. Wu JT, Leung K, Bushman M, Kishore N, Niehus R, de Salazar PM, et al. Estimating 498 clinical severity of COVID-19 from the transmission dynamics in Wuhan, China. Nat Med. 499 2020;26(4):506-10.

500 19. Kucharski AJ, Russell TW, Diamond C, Liu Y, Edmunds J, Funk S, et al. Early dynamics 501 of transmission and control of COVID-19: a mathematical modelling study. Lancet Infect Dis. $502 \quad 2020 ; 20(5): 553-8$.

503 20. Lin Q, Zhao S, Gao D, Lou Y, Yang S, Musa SS, et al. A conceptual model for the 504 coronavirus disease 2019 (COVID-19) outbreak in Wuhan, China with individual reaction and 505 governmental action. Int J Infect Dis. 2020;93:211-6.

506 21. Anastassopoulou C, Russo L, Tsakris A, Siettos C. Data-based analysis, modelling and 507 forecasting of the COVID-19 outbreak. PLoS One. 2020;15(3):e0230405.

508 22. Hellewell J, Abbott S, Gimma A, Bosse NI, Jarvis CI, Russell TW, et al. Feasibility of 509 controlling COVID-19 outbreaks by isolation of cases and contacts. Lancet Glob Health. $510 \quad 2020 ; 8(4): e 488-e 96$.

511 23. Hufnagel L, Brockmann D, Geisel T. Forecast and control of epidemics in a globalized 512 world. Proc Natl Acad Sci U S A. 2004;101(42):15124-9.

513 24. Cliff AD, Ord J, Haggett P, Versey G. Spatial diffusion: an historical geography of 514 epidemics in an island community: CUP Archive; 1981.

515 25. Hägerstrand T. Innovation diffusion as a spatial process. Chicago: University of Chicago 516 Press; 1967. 
517 26. Dalvi APR, Braga JU. Spatial diffusion of the 2015-2016 Zika, dengue and chikungunya 518 epidemics in Rio de Janeiro Municipality, Brazil. Epidemiol Infect. 2019;147:e237.

519 27. Gould PR. Spatial Diffusion. Resource Paper No. 4. 1969. Available from: 520 https://eric.ed.gov/?id=ED120029.

521 28. Golub A, Gorr WL, Gould PR. Spatial diffusion of the Hiv Aids epidemic - Modeling 522 implications and case-study of Aids incidence in Ohio. Geogr Anal. 1993;25(2):85-100.

523 29. Sirkeci I, Yucesahin MM. Coronavirus and migration: Analysis of human mobility and the 524 spread of Covid-19. Migration Letters. 2020;17(2):379-98.

525 30. Memish Z, Assiri A, Turkestani A, Yezli S, Al Masri M, Charrel R, et al. Mass gathering 526 and globalization of respiratory pathogens during the 2013 Hajj. Clin Microbiol Infect. $527 \quad 2015 ; 21(6): 571 . e 1-. e 8$.

528 31. Ali SH, Keil R. Networked disease: emerging infections in the global city. Oxford: John 529 Wiley \& Sons; 2011.

530 32. Zhou YR, Coleman WD. Accelerated contagion and response: understanding the 531 relationships among globalization, time, and disease. Globalizations. 2016;13(3):285-99.

532 33. Farzanegan MR, Feizi M, Gholipour HF. Globalization and outbreak of COVID-19: An 533 empirical analysis. 2020. Joint Discussion Paper Series in Economics. Available from: 534 https://www.econstor.eu/handle/10419/216658.

535 34. Zimmermann KF, Karabulut G, Huseyin Bilgin M, Cansin Doker A. Inter-country 536 distancing, globalization and the Coronavirus pandemic. World Econ. 537 2020; doi.org/10.1111/twec.12969.

538 35. Tatem AJ, Rogers DJ, Hay SI. Global transport networks and infectious disease spread. 539 Adv Parasitol. 2006;62:293-343.

540 36. Candido DDS, Watts A, Abade L, Kraemer MUG, Pybus OG, Croda J, et al. Routes for 541 COVID-19 importation in Brazil. J Travel Med. 2020;doi:10.1093/jtm/taaa042.

542 37. Zhang S, Diao M, Yu W, Pei L, Lin Z, Chen D. Estimation of the reproductive number of 543 novel coronavirus (COVID-19) and the probable outbreak size on the Diamond Princess cruise 544 ship: A data-driven analysis. Int J Infect Dis. 2020;93:201-4.

545 38. Gygli S, Haelg F, Potrafke N, Sturm J-E. The KOF globalisation index-revisited. Rev Int 546 Organ. 2019;14(3):543-74.

547 39. Acuto M. COVID-19: Lessons for an Urban (izing) World. One Earth. 2020;2(4):317-9. 
548 40. Morse SS. Factors in the emergence of infectious diseases. Emerg Infect Dis. 1995;1(1):754915.

550 41. Moore M, Gould P, Keary BS. Global urbanization and impact on health. Int J Hyg Environ 551 Health. 2003;206(4-5):269-78.

552 42. Neiderud C-J. How urbanization affects the epidemiology of emerging infectious diseases. 553 Infect Ecol Epidemiol. 2015;5(1):27060.

554 43. Connolly C, Keil R, Ali SH. Extended urbanisation and the spatialities of infectious 555 disease: Demographic change, infrastructure and governance. Urban Stud. $556 \quad 2020: 0042098020910873$.

557 44. Tarwater PM, Martin CF. Effects of population density on the spread of disease. 558 Complexity. 2001;6(6):29-36.

559 45. Merler S, Ajelli M. The role of population heterogeneity and human mobility in the spread 560 of pandemic influenza. Proc Royal Soc B. 2010;277(1681):557-65.

561 46. Dowd JB, Andriano L, Brazel DM, Rotondi V, Block P, Ding X, et al. Demographic 562 science aids in understanding the spread and fatality rates of COVID-19. Proc Natl Acad Sci U S 563 A. 2020;117(18):9696-8.

564 47. Koenker R, Bassett Jr G. Regression quantiles. Econometrica. 1978;46(1):33-50.

565 48. Yu KM, Lu ZD, Stander J. Quantile regression: applications and current research areas. J 566 Roy Stat Soc D-Sta. 2003;52:331-50.

567 49. UN. The 2019 Revision of World Population Prospects. 2019. Available from: 568 https://population.un.org/wpp/.

569 50. Swenson K. Millions track the pandemic on Johns Hopkins's dashboard. Those who built 570 it say some miss the real story. The Washington Post. 2020.[Accessed: 21 July 2020]. Available

571 from: https://www.washingtonpost.com/local/johns-hopkins-tracker/2020/06/29/daea7eea-a03f-

572 11ea-9590-1858a893bd59_story.html.

573 51. Hegde A, Masthi R, Krishnappa D. Hyperlocal Postcode Based Crowdsourced 574 Surveillance Systems in the COVID-19 Pandemic Response. Public Health Front. 2020;8:286.

575 52. Bommer C, Vollmer S. Average detection rate of SARS-CoV-2 infections is estimated 576 around six percent. 2020; www.uni-goettingen.de/en/606540.html.

577 53. Rasmussen SA, Thompson LA. Coronavirus disease 2019 and children: what pediatric 578 health care clinicians need to know. JAMA pediatrics. 2020;10.1001/jamapediatrics.2020.1224. 
579 54. Koenker R. Quantile Regression. Cambridge: Cambridge University Press; 2005.

580 55. Hao L, Naiman D. Quantile Regression. London: Sage Publications; 2007.

581 56. Wang W, Cook D, Wang E. quokar: Quantile Regression Outlier Diagnostics with K Left

582 Out Analysis2017. Available from: CRAN https://cran.r-

583 project.org/web/packages/quokar/index.html.

584 57. Benites LE, Lachos VH, Vilca FE. Case-deletion diagnostics for Quantile regression using 585 the asymmetric Laplace distribution. arXiv preprint arXiv:150905099. 2015.

586 58. Dreher A. Does globalization affect growth? Evidence from a new index of globalization. 587 Appl Econ. 2006;38(10):1091-110.

588 59. Potrafke N. The evidence on globalisation. World Econ. 2015;38(3):509-52.

589 60. Barnett ED, Walker PF. Role of immigrants and migrants in emerging infectious diseases. 590 Med Clin North Am. 2008;92(6):1447-58.

591 61. Richter LK. International tourism and its global public health consequences. J Travel Res. $592 \quad 2003 ; 41(4): 340-7$.

593 62. MacPherson DW, Gushulak BD. Human mobility and population health: new approaches 594 in a globalizing world. Perspect Biol Med. 2001;44(3):390-401.

595 63. Weiss DJ, Nelson A, Gibson H, Temperley W, Peedell S, Lieber A, et al. A global map of 596 travel time to cities to assess inequalities in accessibility in 2015. Nature. 2018;553(7688):333-6.

597 64. Stier A, Berman M, Bettencourt L. COVID-19 attack rate increases with city size. 598 Mansueto Institute for Urban Innovation Research Paper [Internet]. 2020; Forthcoming. Available 599 from: https://ssrn.com/abstract=3564464.

600 65. Pan A, Liu L, Wang C, Guo H, Hao X, Wang Q, et al. Association of public health 601 interventions with the epidemiology of the COVID-19 outbreak in Wuhan, China. JAMA. 602 2020;323(19):1915-23.

603 66. Chinazzi M, Davis JT, Ajelli M, Gioannini C, Litvinova M, Merler S, et al. The effect of 604 travel restrictions on the spread of the 2019 novel coronavirus (COVID-19) outbreak. Science. $6052020 ; 368(6489): 395-400$.

606 67. Kraemer MU, Yang C-H, Gutierrez B, Wu C-H, Klein B, Pigott DM, et al. The effect of 607 human mobility and control measures on the COVID-19 epidemic in China. Science. $608 \quad 2020 ; 368(6490): 493-7$. 
609 68. Graham-McLay C. New Zealand drops Covid-19 restrictions after nation declared 'virus610 free'. The Guardian. $2020 \quad 8$ June.[Accessed: 12/06/2020]. Available from:

611 https://www.theguardian.com/world/2020/jun/08/new-zealand-abandons-covid-19-restrictions-

612 after-nation-declared-no-cases.

613 69. Bianchi A, Fabrizi E, Salvati N, Tzavidis N. Estimation and testing in M-quantile 614 regression with applications to small area estimation. Int Stat Rev. 2018;86(3):541-70.

615 70. Chambers R, Dreassi E, Salvati N. Disease mapping via negative binomial regression M616 quantiles. Stat Med. 2014;33(27):4805-24.

617 71. Requia WJ, Roig HL, Adams MD, Zanobetti A, Koutrakis P. Mapping distance-decay of 618 cardiorespiratory disease risk related to neighborhood environments. Environ Res. 2016;151:20361915.

620 72. Kim J, Corcoran J, Papamanolis M. Route choice stickiness of public transport passengers: 621 Measuring habitual bus ridership behaviour using smart card data. Transp Res Part C Emerg 622 Technol. 2017;83:146-64.

623 73. Koenker R, Machado JA. Goodness of fit and related inference processes for quantile 624 regression. J Am Stat Assoc. 1999;94(448):1296-310.

625 
626 Additional file 1. Week 10 (ending April 4th) comparison of standardised coefficients at 25th, 50th, 75th 627 and 90th quantiles and the mean function

\begin{tabular}{|c|c|c|c|c|c|}
\hline & \multicolumn{5}{|c|}{ Dependent variable: } \\
\hline & \multirow[t]{2}{*}{$O L S$} & \multirow{2}{*}{\multicolumn{4}{|c|}{$\begin{array}{l}\text { quantile } \\
\text { regression }\end{array}$}} \\
\hline & & & & & \\
\hline & $\begin{array}{l}\text { Mean } \\
\text { Model }\end{array}$ & $\begin{array}{c}25 \text { th } \\
\text { quantile }\end{array}$ & $\begin{array}{c}\text { 50th } \\
\text { quantile }\end{array}$ & $\begin{array}{c}\text { 75th } \\
\text { quantile }\end{array}$ & $\begin{array}{c}\text { 90th } \\
\text { quantile }\end{array}$ \\
\hline \multirow[t]{2}{*}{ Intercept } & $0.663^{* * *}$ & 0.257 & $0.644^{* * *}$ & $1.070^{* * *}$ & $1.490^{* * *}$ \\
\hline & $(0.108)$ & $(0.162)$ & $(0.171)$ & $(0.190)$ & $(0.195)$ \\
\hline \multirow[t]{2}{*}{ Interpersonal Globalisation [index] } & 0.134 & 0.362 & 0.227 & 0.149 & -0.503 \\
\hline & $(0.171)$ & $(0.238)$ & $(0.254)$ & $(0.225)$ & $(0.419)$ \\
\hline \multirow[t]{2}{*}{ Trade Globalisation [index] } & 0.082 & -0.008 & 0.074 & 0.116 & 0.099 \\
\hline & $(0.127)$ & $(0.152)$ & $(0.185)$ & $(0.205)$ & $(0.239)$ \\
\hline \multirow[t]{2}{*}{ Financial Globalisation [index] } & -0.134 & -0.082 & 0.073 & 0.040 & -0.041 \\
\hline & $(0.159)$ & $(0.237)$ & $(0.245)$ & $(0.231)$ & $(0.262)$ \\
\hline \multirow[t]{2}{*}{ Urbanisation [rate] } & -0.024 & 0.086 & 0.030 & -0.071 & -0.065 \\
\hline & $(0.129)$ & $(0.162)$ & $(0.180)$ & $(0.203)$ & $(0.264)$ \\
\hline \multirow[t]{2}{*}{ Population Density [log] } & $0.505^{* * *}$ & $0.441^{* *}$ & $0.416^{* *}$ & 0.408 & 0.519 \\
\hline & $(0.156)$ & $(0.185)$ & $(0.204)$ & $(0.247)$ & $(0.349)$ \\
\hline \multirow[t]{2}{*}{ Urban Density [maximum] } & $-0.357^{* *}$ & $-0.383^{* *}$ & -0.191 & -0.133 & -0.145 \\
\hline & $(0.147)$ & $(0.163)$ & $(0.202)$ & $(0.495)$ & $(0.689)$ \\
\hline \multirow[t]{2}{*}{ Areal Accessibility [mean] } & $0.311^{* *}$ & 0.300 & 0.335 & 0.218 & -0.015 \\
\hline & $(0.155)$ & $(0.197)$ & $(0.229)$ & $(0.367)$ & $(0.416)$ \\
\hline \multirow[t]{2}{*}{ Human Development [index] } & $0.636^{* * *}$ & 0.396 & 0.462 & 0.477 & $0.959^{* *}$ \\
\hline & $(0.210)$ & $(0.290)$ & $(0.322)$ & $(0.337)$ & $(0.394)$ \\
\hline \multirow[t]{2}{*}{ Population aged 65 and over [\%] } & $0.337^{*}$ & 0.344 & $0.408^{*}$ & 0.393 & 0.237 \\
\hline & $(0.179)$ & $(0.220)$ & $(0.238)$ & $(0.271)$ & $(0.365)$ \\
\hline \multirow[t]{2}{*}{ Household Size [mean] } & $0.344^{* *}$ & $0.356^{*}$ & $0.442^{* *}$ & $0.384^{* *}$ & 0.402 \\
\hline & $(0.144)$ & $(0.208)$ & $(0.194)$ & $(0.179)$ & $(0.277)$ \\
\hline \multirow[t]{2}{*}{ Population [n] } & $0.165^{*}$ & 0.061 & 0.039 & $0.415^{* *}$ & 0.156 \\
\hline & $(0.091)$ & $(0.151)$ & $(0.188)$ & $(0.173)$ & $(0.213)$ \\
\hline \multirow{2}{*}{$\begin{array}{l}\text { Financial:Interpersonal } \\
\text { Globalisation }\end{array}$} & $0.211^{* *}$ & $0.284^{*}$ & 0.129 & 0.169 & 0.354 \\
\hline & $(0.102)$ & $(0.145)$ & $(0.153)$ & $(0.177)$ & $(0.229)$ \\
\hline \multirow[t]{2}{*}{ Urban Density:Areal Accessibility } & 0.048 & -0.027 & 0.074 & -0.136 & -0.343 \\
\hline & $(0.090)$ & $(0.112)$ & $(0.130)$ & $(0.377)$ & $(0.452)$ \\
\hline Observations & 84 & 84 & 84 & 84 & 84 \\
\hline $\mathrm{R}^{2}$ & 0.678 & & & & \\
\hline Adjusted $\mathrm{R}^{2}$ & 0.619 & & & & \\
\hline Residual Std. Error & 0.679 & & & & \\
\hline
\end{tabular}


F Statistic

Note:
$11.400^{* * *}$

629 Additional file 2. Week 11 (ending March 11th) comparison of standardised coefficients at 25th, 50th, 630 75th and 90th quantiles and the mean function

\begin{tabular}{|c|c|c|c|c|c|}
\hline & \multicolumn{5}{|c|}{ Dependent variable: } \\
\hline & \multirow{2}{*}{$\begin{array}{c}\text { OLS } \\
\text { Mean } \\
\text { Model }\end{array}$} & \multicolumn{4}{|c|}{$\begin{array}{l}\text { quantile } \\
\text { regression }\end{array}$} \\
\hline & & $\begin{array}{c}25 \text { th } \\
\text { quantile }\end{array}$ & $\begin{array}{c}50 \text { th } \\
\text { quantile }\end{array}$ & $\begin{array}{c}75 \text { th } \\
\text { quantile }\end{array}$ & $\begin{array}{c}\text { 90th } \\
\text { quantile }\end{array}$ \\
\hline \multirow[t]{2}{*}{ Intercept } & $1.460^{* * *}$ & $1.210^{* * *}$ & $1.440^{* * *}$ & $1.790^{* * *}$ & $2.100^{* * *}$ \\
\hline & $(0.089)$ & $(0.101)$ & $(0.121)$ & $(0.148)$ & $(0.174)$ \\
\hline \multirow[t]{2}{*}{ Interpersonal Globalisation [index] } & 0.104 & $0.251^{*}$ & 0.110 & 0.031 & -0.033 \\
\hline & $(0.141)$ & $(0.145)$ & $(0.149)$ & $(0.201)$ & $(0.316)$ \\
\hline \multirow{2}{*}{ Trade Globalisation [index] } & 0.049 & 0.033 & 0.047 & 0.058 & -0.161 \\
\hline & $(0.105)$ & $(0.111)$ & $(0.125)$ & $(0.170)$ & $(0.208)$ \\
\hline \multirow[t]{2}{*}{ Financial Globalisation [index] } & 0.030 & 0.141 & 0.171 & 0.234 & 0.121 \\
\hline & $(0.131)$ & $(0.146)$ & $(0.155)$ & $(0.168)$ & $(0.212)$ \\
\hline \multirow[t]{2}{*}{ Urbanisation [rate] } & -0.014 & 0.077 & 0.072 & -0.012 & -0.184 \\
\hline & $(0.106)$ & $(0.104)$ & $(0.116)$ & $(0.161)$ & $(0.238)$ \\
\hline \multirow[t]{2}{*}{ Population Density [log] } & $0.262^{* *}$ & $0.223^{*}$ & 0.271 & 0.273 & 0.342 \\
\hline & $(0.129)$ & $(0.121)$ & $(0.170)$ & $(0.250)$ & $(0.301)$ \\
\hline \multirow[t]{2}{*}{ Urban Density [maximum] } & $-0.205^{*}$ & -0.171 & -0.130 & -0.123 & 0.059 \\
\hline & $(0.121)$ & $(0.107)$ & $(0.124)$ & $(0.242)$ & $(0.599)$ \\
\hline \multirow[t]{2}{*}{ Areal Accessibility [mean] } & 0.141 & 0.123 & 0.127 & 0.101 & -0.149 \\
\hline & $(0.128)$ & $(0.131)$ & $(0.156)$ & $(0.240)$ & $(0.336)$ \\
\hline \multirow[t]{2}{*}{ Human Development [index] } & $0.629^{* * *}$ & 0.261 & $0.393^{*}$ & $0.481^{*}$ & $0.786^{* *}$ \\
\hline & $(0.174)$ & $(0.182)$ & (0.199) & $(0.255)$ & $(0.304)$ \\
\hline \multirow[t]{2}{*}{ Population aged 65 and over [\%] } & 0.235 & $0.269^{* *}$ & $0.354^{*}$ & 0.388 & 0.114 \\
\hline & $(0.148)$ & $(0.133)$ & $(0.195)$ & $(0.282)$ & $(0.332)$ \\
\hline \multirow[t]{2}{*}{ Household Size [mean] } & $0.292^{* *}$ & $0.274^{* *}$ & $0.332^{* *}$ & $0.338^{* *}$ & 0.183 \\
\hline & $(0.118)$ & $(0.110)$ & $(0.135)$ & $(0.167)$ & $(0.225)$ \\
\hline \multirow[t]{2}{*}{ Population [n] } & 0.100 & -0.001 & -0.023 & $0.310^{* *}$ & 0.137 \\
\hline & $(0.075)$ & $(0.113)$ & $(0.122)$ & $(0.131)$ & $(0.162)$ \\
\hline \multirow[t]{2}{*}{$\begin{array}{l}\text { Financial:Interpersonal } \\
\text { Globalisation }\end{array}$} & $0.160^{*}$ & 0.160 & 0.108 & 0.102 & $0.367^{*}$ \\
\hline & $(0.084)$ & $(0.101)$ & $(0.113)$ & $(0.145)$ & $(0.211)$ \\
\hline Urban Density:Areal Accessibility & 0.122 & 0.075 & 0.122 & 0.044 & -0.308 \\
\hline
\end{tabular}




\begin{tabular}{lccccc} 
& $(0.075)$ & $(0.072)$ & $(0.081)$ & $(0.194)$ & $(0.405)$ \\
\hline Observations & 84 & 84 & 84 & 84 & 84 \\
$\mathrm{R}^{2}$ & 0.735 & & & & \\
Adjusted R & 0.686 & & & & \\
Residual Std. Error & 0.560 & & & & \\
F Statistic & $14.900^{* * *}$ & & & & \\
\hline Note: & & & & ${ }^{*} \mathrm{p}^{* *} \mathrm{p}^{* * *} \mathrm{p}<0.01$
\end{tabular}

632 Additional file 3. Week 12 (ending March 18th) comparison of standardised coefficients at 25th, 50th, 633 75th and 90th quantiles and the mean function

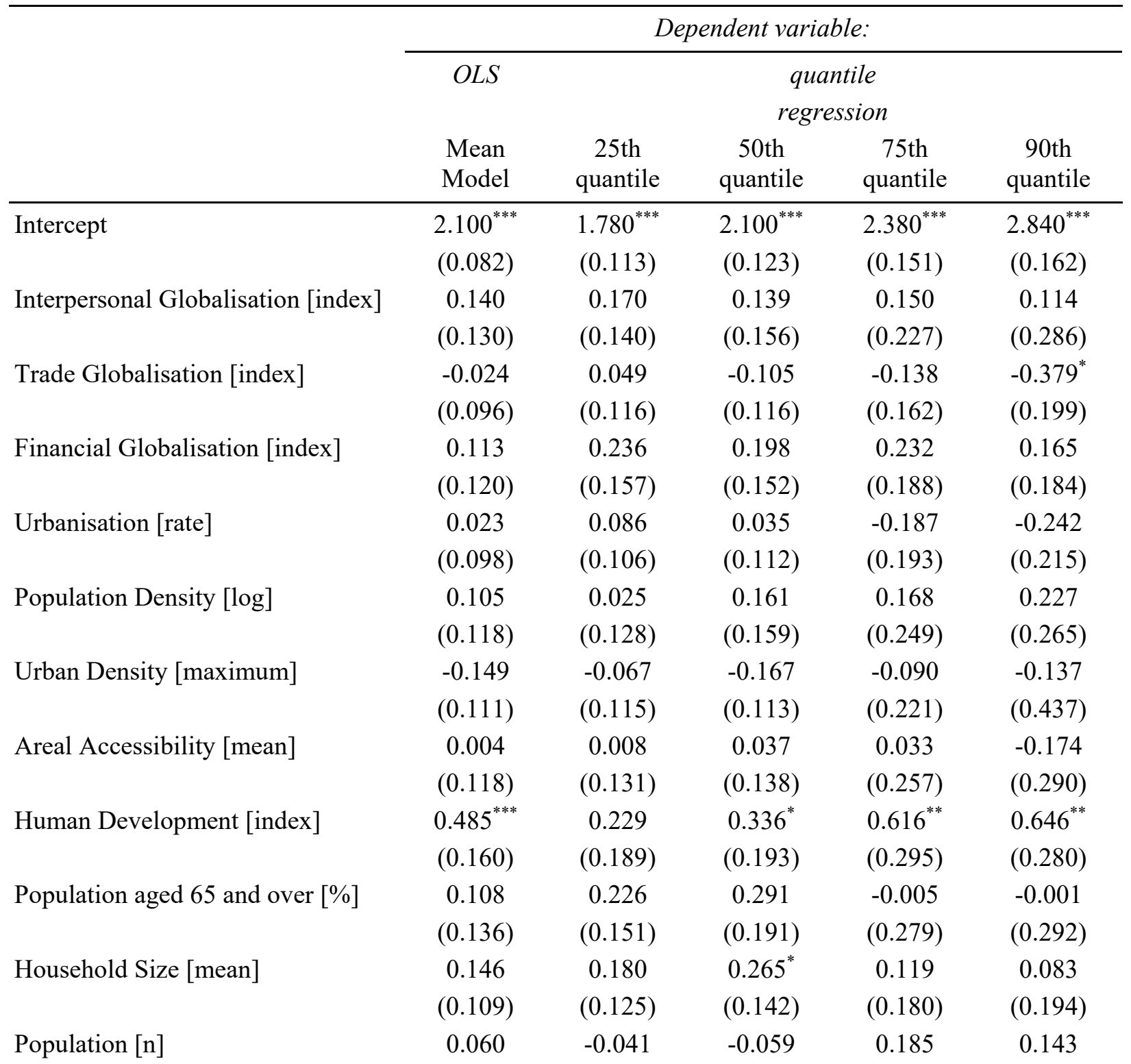




\begin{tabular}{lccccc} 
& $(0.069)$ & $(0.119)$ & $(0.111)$ & $(0.154)$ & $(0.155)$ \\
Financial:Interpersonal & $0.142^{*}$ & $0.199^{*}$ & 0.101 & 0.091 & 0.105 \\
Globalisation & $(0.077)$ & $(0.104)$ & $(0.115)$ & $(0.149)$ & $(0.162)$ \\
Urban Density:Areal Accessibility & $0.138^{* *}$ & 0.104 & 0.098 & 0.171 & -0.249 \\
& $(0.069)$ & $(0.072)$ & $(0.071)$ & $(0.212)$ & $(0.315)$ \\
\hline Observations & 84 & 84 & 84 & 84 & 84 \\
$\mathrm{R}^{2}$ & 0.729 & & & & \\
Adjusted R & & & & & \\
Residual Std. Error & 0.679 & & & & \\
F Statistic & 0.515 & & & & \\
\hline Note: & $14.500^{* * *}$ & & & & \\
& & & & & \\
\end{tabular}

634

635

636 Additional file 4. Week 13 (ending March 25th) comparison of standardised coefficients at 25th, 50th, 637 75th and 90th quantiles and the mean function

\begin{tabular}{lccccc}
\hline & \multicolumn{5}{c}{ Dependent variable: } \\
\cline { 2 - 6 } & OLS & \multicolumn{4}{c}{ quantile } \\
& Mean & 25 th & 50th & 75 th & 90th \\
& Model & quantile & quantile & quantile & quantile \\
\hline Intercept & $2.580^{* * *}$ & $2.270^{* * *}$ & $2.590^{* * *}$ & $2.930^{* * *}$ & $3.190^{* * *}$ \\
& $(0.077)$ & $(0.124)$ & $(0.144)$ & $(0.141)$ & $(0.124)$ \\
Interpersonal Globalisation [index] & 0.184 & 0.240 & 0.172 & 0.184 & 0.097 \\
& $(0.122)$ & $(0.158)$ & $(0.186)$ & $(0.216)$ & $(0.231)$ \\
Trade Globalisation [index] & -0.072 & -0.034 & -0.095 & -0.248 & $-0.311^{*}$ \\
& $(0.091)$ & $(0.116)$ & $(0.138)$ & $(0.151)$ & $(0.157)$ \\
Financial Globalisation [index] & 0.141 & 0.244 & 0.168 & 0.223 & 0.148 \\
Urbanisation [rate] & $(0.114)$ & $(0.161)$ & $(0.182)$ & $(0.185)$ & $(0.159)$ \\
& 0.053 & 0.040 & 0.110 & -0.176 & -0.148 \\
Population Density [log] & $(0.092)$ & $(0.101)$ & $(0.131)$ & $(0.195)$ & $(0.188)$ \\
& -0.009 & -0.024 & 0.008 & 0.322 & 0.191 \\
Urban Density [maximum] & $(0.112)$ & $(0.142)$ & $(0.192)$ & $(0.244)$ & $(0.213)$ \\
Areal Accessibility [mean] & -0.112 & -0.053 & -0.139 & -0.039 & -0.224 \\
Human Development [index] & $(0.105)$ & $(0.110)$ & $(0.132)$ & $(0.248)$ & $(0.329)$ \\
& -0.096 & -0.029 & -0.121 & 0.150 & -0.138 \\
& $(0.111)$ & $(0.132)$ & $(0.167)$ & $(0.307)$ & $(0.227)$ \\
& $0.408^{* * *}$ & 0.235 & 0.226 & $0.562^{*}$ & $0.432^{*}$ \\
& $(0.151)$ & $(0.183)$ & $(0.223)$ & $(0.285)$ & $(0.241)$
\end{tabular}




\begin{tabular}{lccccc} 
Population aged 65 and over [\%] & 0.037 & 0.219 & 0.178 & 0.169 & 0.144 \\
Household Size [mean] & $(0.128)$ & $(0.170)$ & $(0.235)$ & $(0.221)$ & $(0.233)$ \\
& 0.070 & 0.141 & 0.102 & 0.134 & 0.077 \\
Population [n] & $(0.103)$ & $(0.142)$ & $(0.172)$ & $(0.162)$ & $(0.157)$ \\
& 0.044 & -0.030 & -0.048 & 0.070 & 0.104 \\
Financial:Interpersonal & $(0.065)$ & $(0.108)$ & $(0.134)$ & $(0.165)$ & $(0.128)$ \\
Globalisation & $0.130^{*}$ & $0.191^{*}$ & 0.093 & 0.016 & 0.102 \\
& $(0.073)$ & $(0.111)$ & $(0.133)$ & $(0.157)$ & $(0.135)$ \\
Urban Density:Areal Accessibility & $0.151^{* *}$ & $0.134^{* *}$ & 0.128 & 0.209 & -0.182 \\
& $(0.065)$ & $(0.065)$ & $(0.084)$ & $(0.321)$ & $(0.250)$ \\
\hline Observations & 84 & 84 & 84 & 84 & 84 \\
$\mathrm{R}^{2}$ & 0.741 & & & & \\
Adjusted R & 0.693 & & & & \\
Residual Std. Error & 0.487 & & & & ${ }^{*} \mathrm{p}^{* *} \mathrm{p}^{* * *} \mathrm{p}<0.01$ \\
F Statistic & $15.400^{* * *}$ & & &
\end{tabular}

640 Additional file 5. Week 14 (ending April 1st) comparison of standardised coefficients at 25th, 50th, 75th 641 and 90th quantiles and the mean function

\begin{tabular}{lccccc}
\hline & \multicolumn{5}{c}{ Dependent variable: } \\
\cline { 2 - 6 } & OLS & \multicolumn{4}{c}{ regression } \\
& Mean Model 25 th quantile 50 th quantile 75 th quantile \\
\hline Intercept & $2.920^{* * *}$ & $2.600^{* * *}$ & $2.950^{* * *}$ & $3.270^{* * *}$ & $3.450^{* * *}$ \\
& $(0.073)$ & $(0.128)$ & $(0.149)$ & $(0.127)$ & $(0.113)$ \\
Interpersonal Globalisation [index] & $0.220^{*}$ & $0.299^{*}$ & 0.180 & 0.155 & 0.131 \\
& $(0.116)$ & $(0.169)$ & $(0.195)$ & $(0.179)$ & $(0.207)$ \\
Trade Globalisation [index] & -0.089 & -0.074 & -0.154 & $-0.297^{* *}$ & $-0.307^{* *}$ \\
& $(0.086)$ & $(0.121)$ & $(0.137)$ & $(0.141)$ & $(0.140)$ \\
Financial Globalisation [index] & 0.142 & 0.247 & 0.076 & 0.266 & 0.076 \\
& $(0.108)$ & $(0.167)$ & $(0.191)$ & $(0.174)$ & $(0.151)$ \\
Urbanisation [rate] & 0.078 & 0.062 & 0.046 & -0.059 & -0.069 \\
& $(0.088)$ & $(0.109)$ & $(0.161)$ & $(0.182)$ & $(0.179)$ \\
Population Density [log] & -0.101 & -0.076 & 0.013 & 0.177 & 0.099 \\
& $(0.106)$ & $(0.148)$ & $(0.203)$ & $(0.227)$ & $(0.196)$ \\
Urban Density [maximum] & -0.079 & -0.035 & -0.187 & 0.002 & -0.271
\end{tabular}




\begin{tabular}{lccccc} 
& $(0.100)$ & $(0.120)$ & $(0.149)$ & $(0.254)$ & $(0.288)$ \\
Areal Accessibility [mean] & -0.172 & -0.079 & -0.118 & -0.028 & -0.192 \\
& $(0.105)$ & $(0.141)$ & $(0.169)$ & $(0.362)$ & $(0.209)$ \\
Human Development [index] & $0.364^{* *}$ & 0.199 & 0.363 & 0.458 & 0.313 \\
& $(0.143)$ & $(0.193)$ & $(0.258)$ & $(0.277)$ & $(0.228)$ \\
Population aged 65 and over [\%] & -0.018 & 0.167 & 0.143 & 0.075 & 0.186 \\
& $(0.122)$ & $(0.174)$ & $(0.240)$ & $(0.207)$ & $(0.214)$ \\
Household Size [mean] & 0.023 & 0.139 & 0.096 & 0.029 & 0.057 \\
& $(0.098)$ & $(0.141)$ & $(0.186)$ & $(0.142)$ & $(0.141)$ \\
Population [n] & 0.044 & 0.006 & -0.024 & 0.033 & 0.067 \\
& $(0.062)$ & $(0.119)$ & $(0.135)$ & $(0.158)$ & $(0.123)$ \\
Financial:Interpersonal Globalisation & $0.136^{*}$ & $0.200^{*}$ & 0.093 & 0.042 & 0.116 \\
& $(0.069)$ & $(0.119)$ & $(0.135)$ & $(0.199)$ & $(0.113)$ \\
Urban Density:Areal Accessibility & $0.168^{* * *}$ & $0.157^{* *}$ & 0.132 & 0.188 & -0.066 \\
& $(0.061)$ & $(0.072)$ & $(0.086)$ & $(0.455)$ & $(0.212)$ \\
\hline Observations & 84 & 84 & 84 & 84 & 84 \\
$\mathrm{R}^{2}$ & 0.755 & & & & \\
Adjusted R ${ }^{2}$ & 0.710 & & & & \\
Residual Std. Error & 0.462 & & & & \\
F Statistic & $16.600^{* * *}$ & & & & \\
\hline Note: & & & & & \\
\hline
\end{tabular}

642 Additional file 6. Week 15 (ending April 8th) comparison of standardised coefficients at 25th, 50th, 75th 643 and 90th quantiles and the mean function

\begin{tabular}{lccccc}
\hline & \multicolumn{5}{c}{ Dependent variable: } \\
\cline { 2 - 6 } & OLS & \multicolumn{4}{c}{ quantile } \\
& Mean & 25th & 50th & 75th & 90th \\
& Model & quantile & quantile & quantile & quantile \\
\hline Intercept & $3.200^{* * *}$ & $2.810^{* * *}$ & $3.160^{* * *}$ & $3.530^{* * *}$ & $3.650^{* * *}$ \\
& $(0.070)$ & $(0.116)$ & $(0.137)$ & $(0.111)$ & $(0.104)$ \\
Interpersonal Globalisation [index] & $0.241^{* *}$ & $0.368^{* *}$ & 0.221 & 0.194 & 0.146 \\
& $(0.111)$ & $(0.149)$ & $(0.178)$ & $(0.155)$ & $(0.187)$ \\
Trade Globalisation [index] & -0.095 & -0.065 & -0.154 & $-0.279^{* *}$ & $-0.331^{* * *}$ \\
& $(0.082)$ & $(0.115)$ & $(0.123)$ & $(0.109)$ & $(0.124)$ \\
Financial Globalisation [index] & 0.148 & 0.141 & 0.095 & 0.239 & 0.125 \\
& $(0.103)$ & $(0.171)$ & $(0.165)$ & $(0.145)$ & $(0.141)$ \\
Urbanisation [rate] & 0.098 & 0.138 & 0.073 & 0.003 & 0.015 \\
& $(0.084)$ & $(0.104)$ & $(0.144)$ & $(0.163)$ & $(0.163)$
\end{tabular}




\begin{tabular}{lccccc} 
Population Density [log] & $-0.172^{*}$ & -0.166 & -0.019 & 0.094 & -0.010 \\
Urban Density [maximum] & $(0.101)$ & $(0.121)$ & $(0.183)$ & $(0.160)$ & $(0.172)$ \\
& -0.011 & -0.005 & -0.157 & 0.036 & -0.174 \\
Areal Accessibility [mean] & $(0.095)$ & $(0.114)$ & $(0.136)$ & $(0.210)$ & $(0.172)$ \\
& $-0.238^{* *}$ & -0.130 & -0.142 & -0.041 & $-0.275^{*}$ \\
Human Development [index] & $(0.100)$ & $(0.130)$ & $(0.149)$ & $(0.173)$ & $(0.162)$ \\
& $0.360^{* *}$ & 0.169 & 0.307 & $0.449^{*}$ & 0.290 \\
Population aged 65 and over [\%] & $(0.136)$ & $(0.192)$ & $(0.232)$ & $(0.240)$ & $(0.221)$ \\
& -0.071 & 0.039 & 0.087 & 0.009 & -0.030 \\
Household Size [mean] & $(0.116)$ & $(0.147)$ & $(0.215)$ & $(0.192)$ & $(0.186)$ \\
& -0.005 & 0.012 & 0.066 & -0.017 & -0.079 \\
Population [n] & $(0.093)$ & $(0.128)$ & $(0.164)$ & $(0.125)$ & $(0.129)$ \\
Financial:Interpersonal & 0.034 & 0.002 & -0.031 & 0.004 & 0.016 \\
Globalisation & $(0.059)$ & $(0.111)$ & $(0.119)$ & $(0.067)$ & $(0.102)$ \\
& $0.134^{* *}$ & $0.278^{* * *}$ & 0.155 & 0.012 & 0.106 \\
Urban Density:Areal Accessibility & $(0.066)$ & $(0.100)$ & $(0.121)$ & $(0.097)$ & $(0.090)$ \\
& $0.169^{* * *}$ & $0.154^{* *}$ & 0.104 & $0.276^{*}$ & 0.110 \\
\hline Observations & $(0.059)$ & $(0.066)$ & $(0.075)$ & $(0.148)$ & $(0.112)$ \\
R $^{2}$ & 84 & 84 & 84 & 84 & 84 \\
Adjusted R ${ }^{2}$ & 0.766 & & & & \\
Residual Std. Error & 0.722 & & & & ${ }^{* * *} \mathrm{p}^{* * *} \mathrm{p}<0.01$ \\
F Statistic & 0.440 & & & & \\
\hline Note: & $17.600^{* * *}$ & & & & \\
\end{tabular}




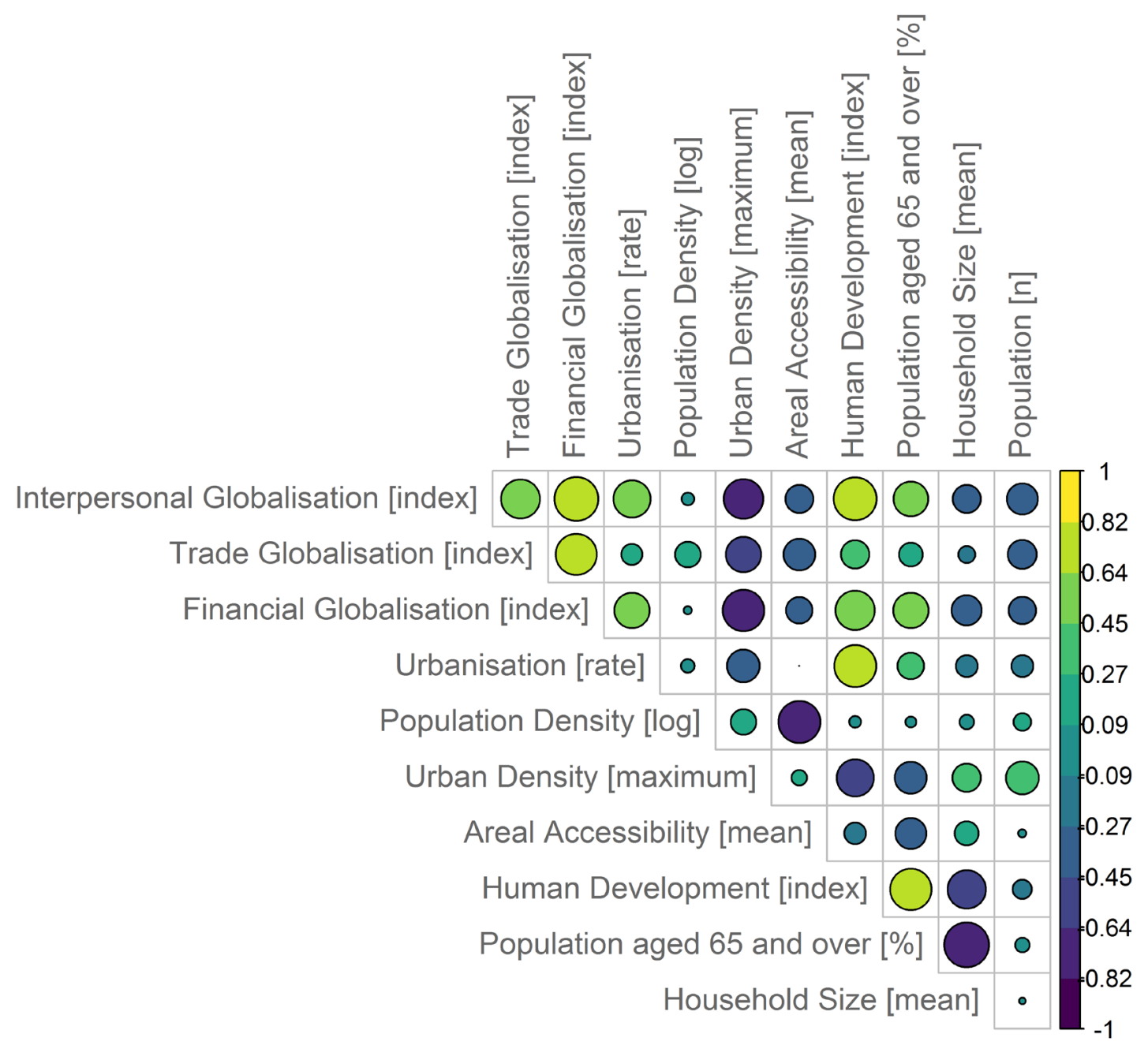

648

649 This depicts collinearities among the independent variables that is particularly pronounced 650 between the human development index and globalization indices. 


\section{Figures}

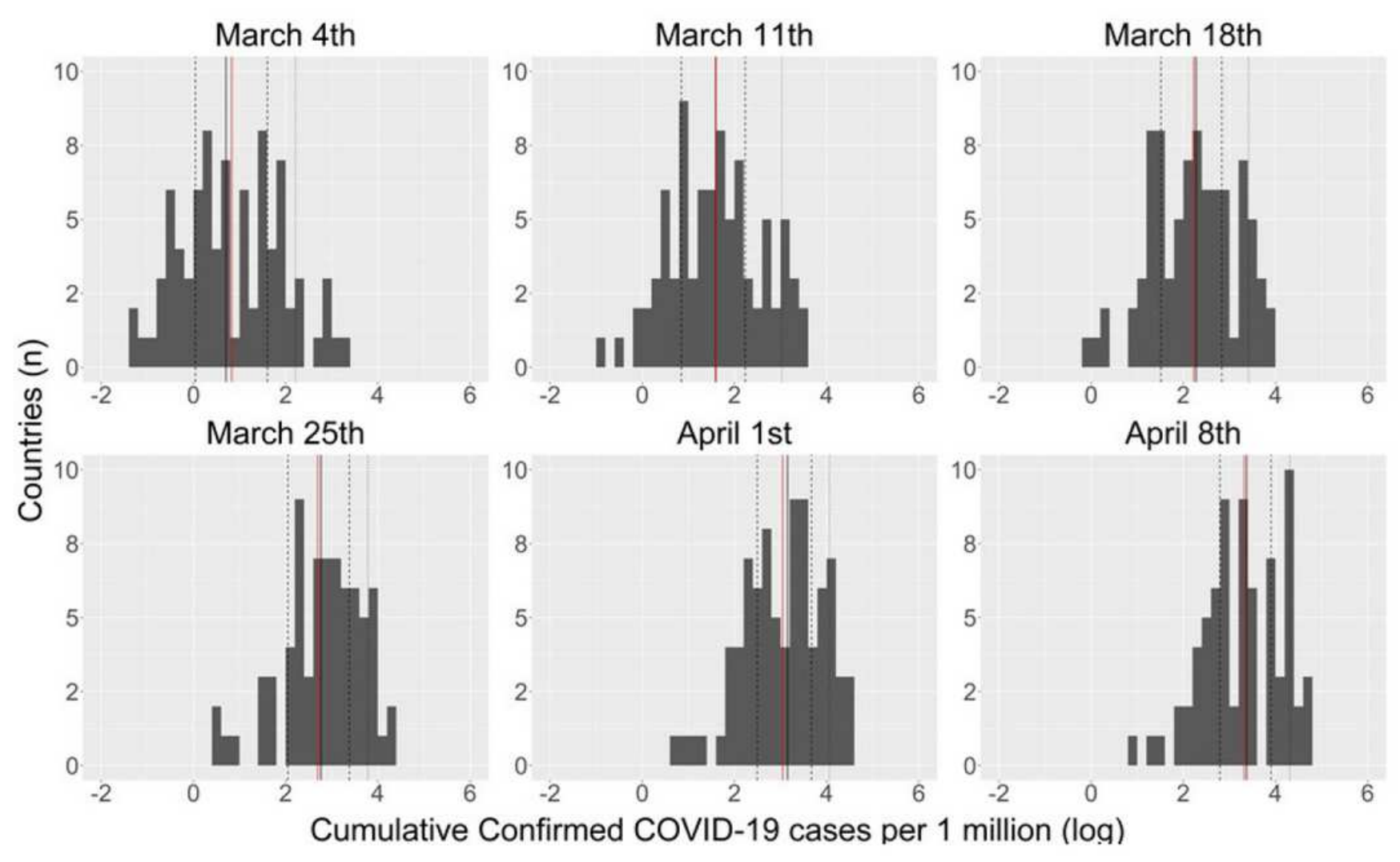

Figure 1

Distributions of cumulative confirmed COVID-19 cases per million population (log transformed). Graphs show the 10th week (ending March 4th) until the 15th week (ending April 8th) of 2020. The red line indicates the mean and the black lines quantiles. 

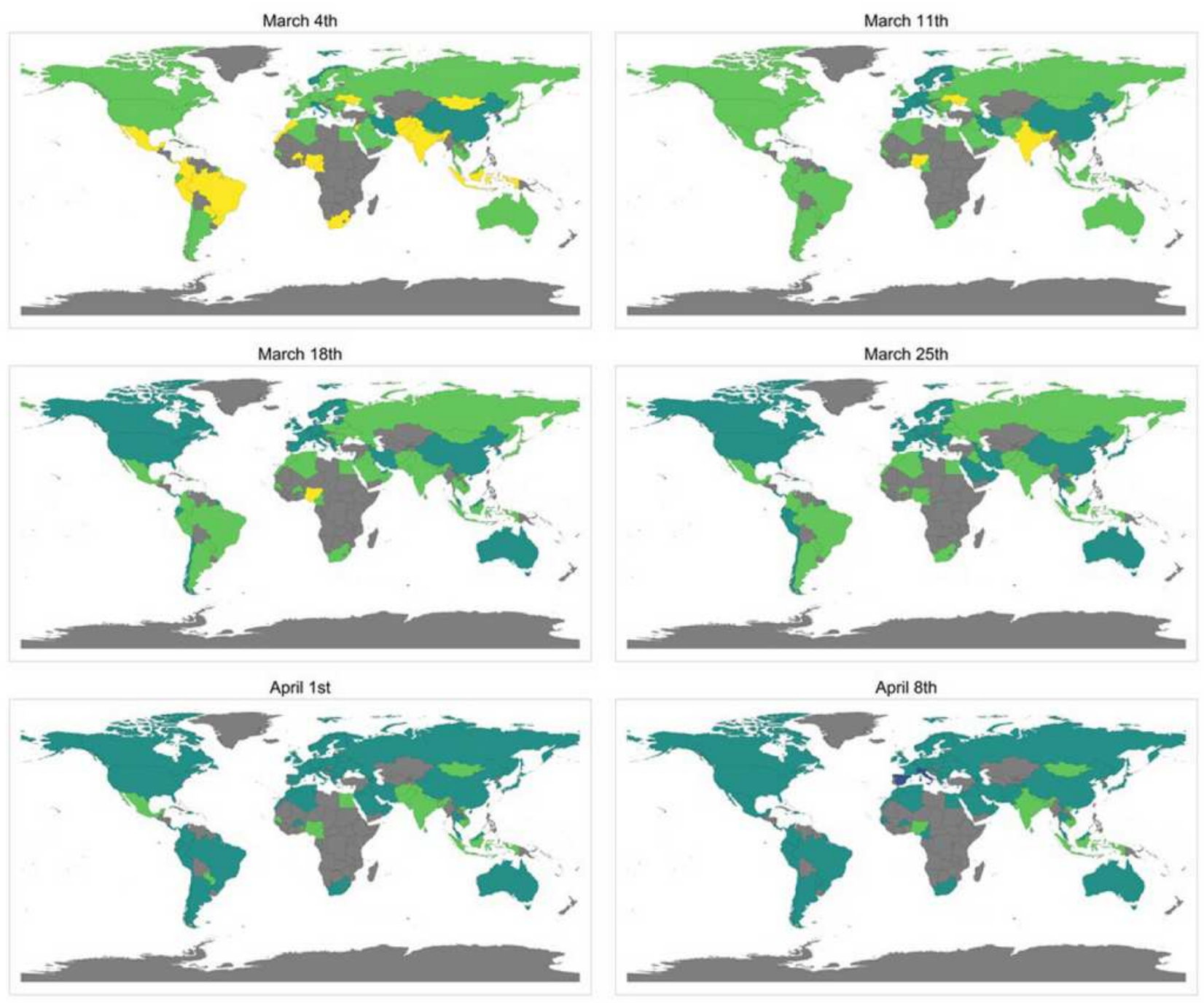

Cumulative Confirmed

Cases per million

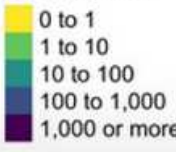

Figure 2

Choropleth map of confirmed cases of COVID 19 per million population for the 84 countries included in the analysis over weeks 10 to 16 (ending March 4th and April 8th 2020, respectively). 


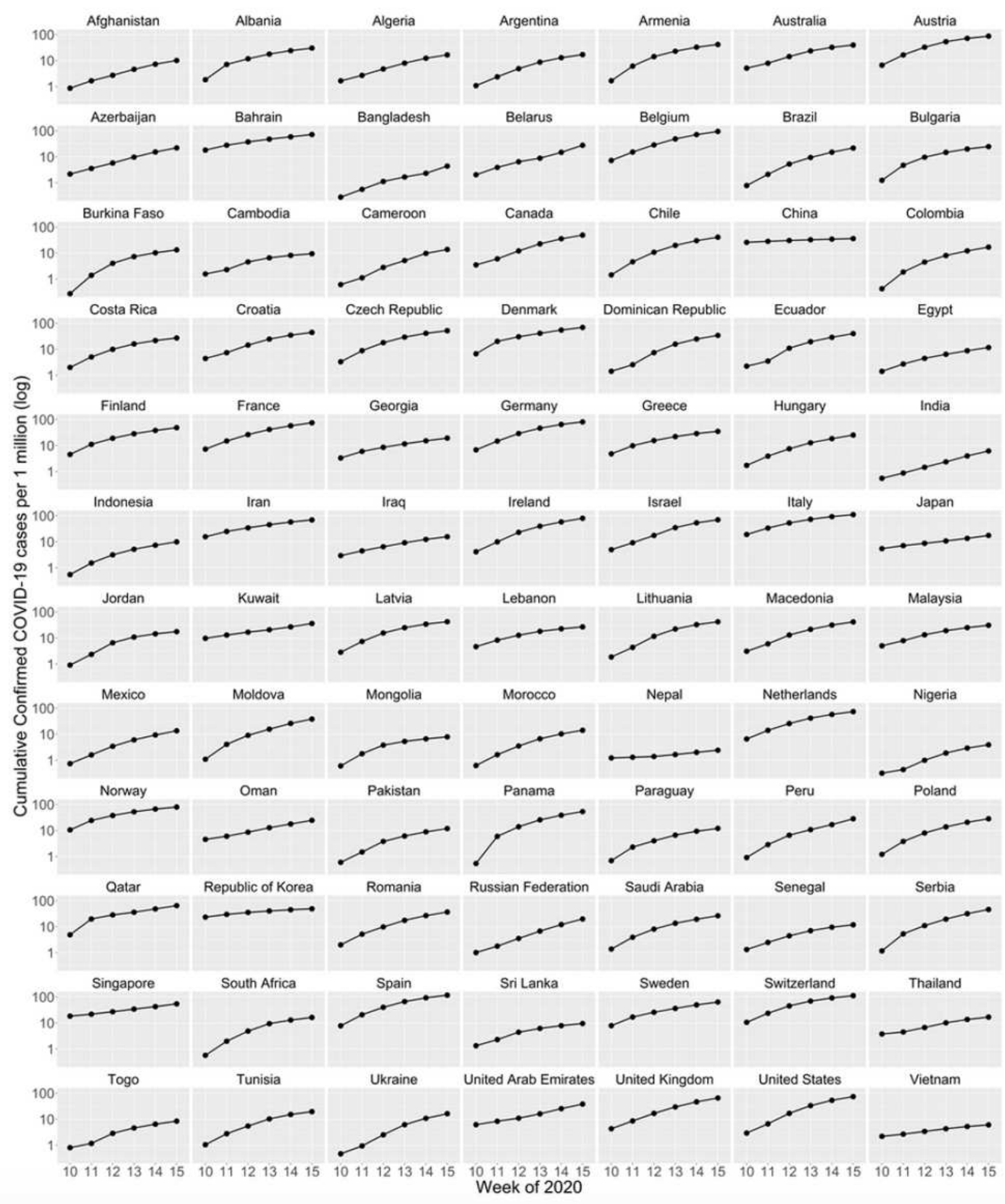

Figure 3

Diffusion of Covid-19 cases per million population (log transformed) over weeks 10 - 15 (ending 4th March and April 8th 2020, respectively) across 84 countries. 

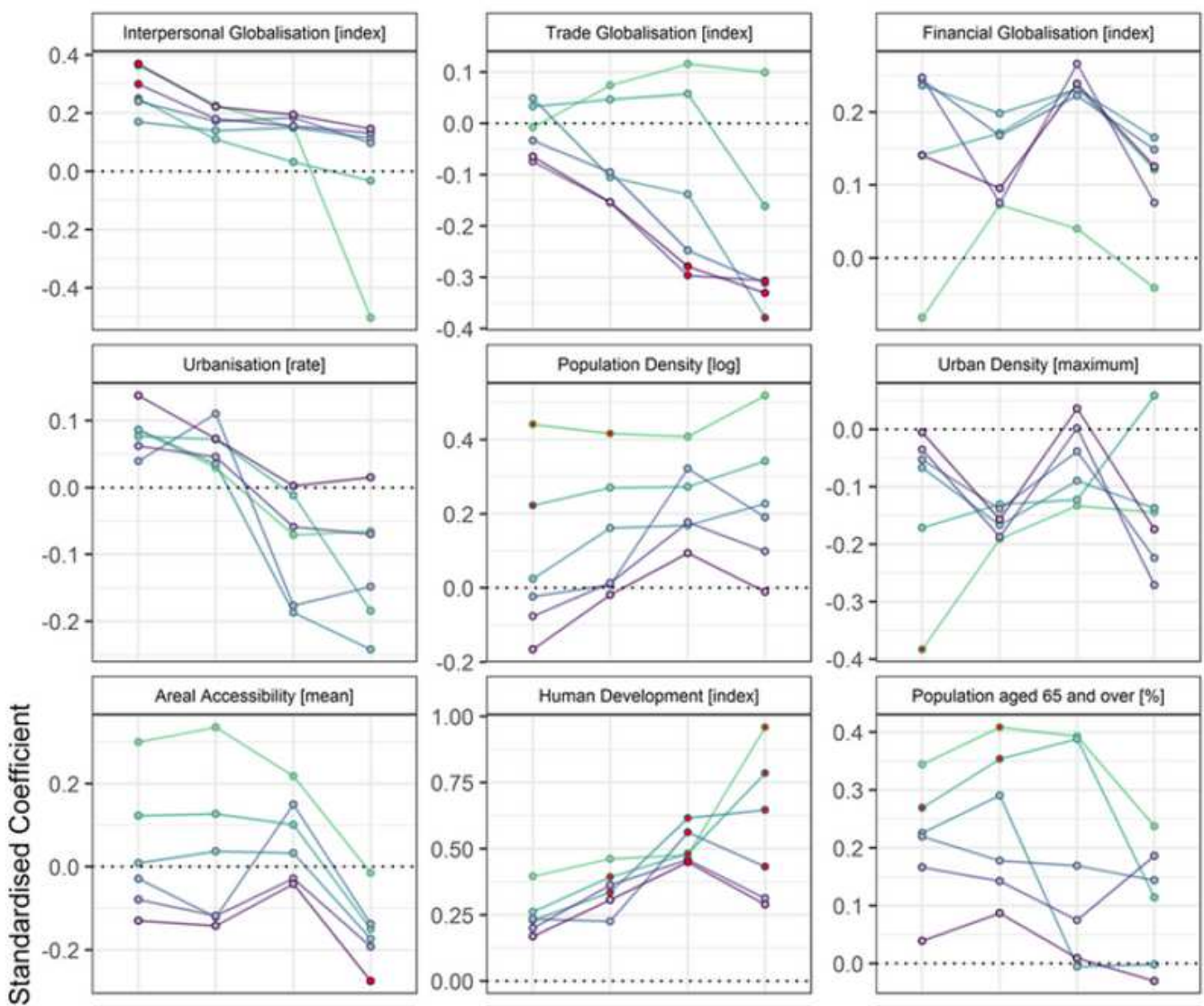

Week Ending:

$\because$ March 4th

$\rightarrow$ March 11th

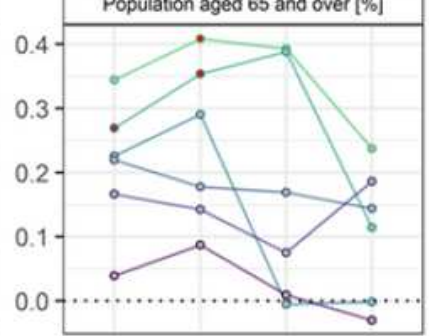

- March 18th

$\because-$ March 25th

$\rightarrow$ April 1st

$\rightarrow$ April 8th
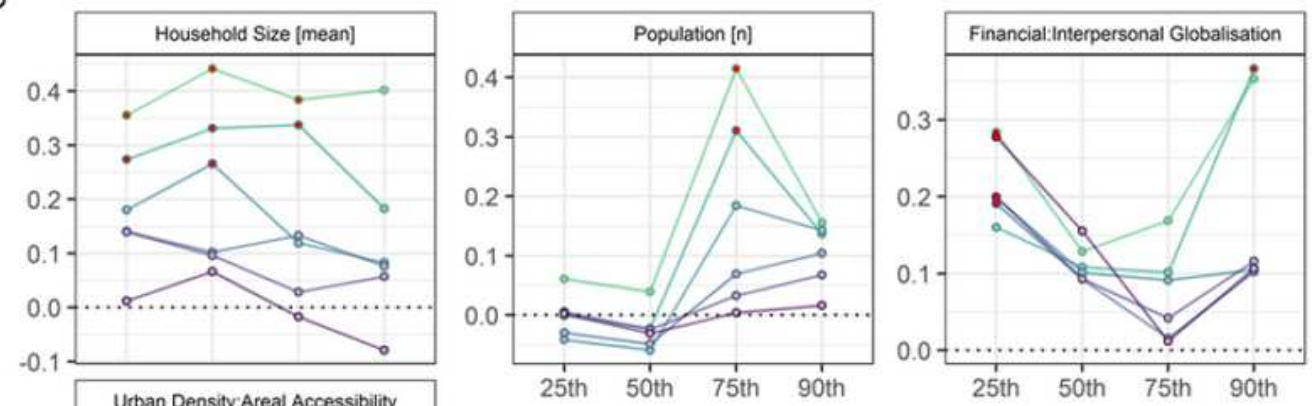

Statistically:

- significant

- insignificant

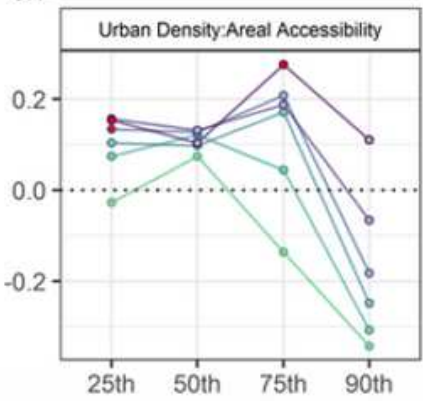

\section{Model Quantile}

\section{Figure 4}

Standardised coefficient value of confirmed COVID-19 cases at the 25th, 50th, 75th and 90th quantiles the 10th week (ending March 4th) until the 15th week of 2020 (ending April 8th). 